\title{
Characterization of various cell lines from different ampullary cancer subtypes and cancer associated fibroblast-mediated responses
}

Zon Weng Lai ${ }^{1 \dagger}$, Louisa Bolm² ${ }^{2 \dagger}$, Hannah Fuellgraf', Martin L. Biniossek', Frank Makowiec ${ }^{4}$, Ulrich Theodor Hopt ${ }^{4,9}$, Martin Werner ${ }^{3,7,8}$, Tobias Keck ${ }^{2}$, Dirk Bausch², Claudio Sorio ${ }^{5}$, Aldo Scarpa ${ }^{5}$, Oliver Schilling ${ }^{1,6,7^{*}}$,

Peter Bronsert ${ }^{3,7,8+}$ and Ulrich Friedrich Wellner $2,8,9+$

\begin{abstract}
Background: Ampullary cancer is a relatively rare form of cancer and usually treated by pancreatoduodenectomy, followed by adjuvant therapy. The intestinal subtype is associated with markedly improved prognosis after resection. At present, only few cell lines are available for in vitro studies of ampullary cancer and they have not been collectively characterized.

Methods: We characterize five ampullary cancer cell lines by subtype maker expression, epithelial-mesenchymal transition (EMT) features, growth and invasion, drug sensitivity and response to cancer-associated fibroblast conditioned medium (CAF-CM).
\end{abstract}

Results: On the basis of EMT features, subtype marker expression, growth, invasion and drug sensitivity three types of cell lines could be distinguished: mesenchymal-like, pancreatobiliary-like and intestinal-like. Heterogeneous effects from the cell lines in response to CAF-CM, such as different growth rates, induction of EMT markers as well as suppression of intestinal differentiation markers were observed. In addition, proteomic analysis showed a clear difference in intestinal-like cell line from other cell lines.

Conclusion: Most of the available AMPAC cell lines seem to reflect a poorly differentiated pancreatobiliary or mesenchymal-like phenotype, which is consistent to their origin. We suggest that the most appropriate cell line model for intestinal-like AMPAC is the SNU869, while others seem to reflect aggressive AMPAC subtypes.

Keywords: Ampullary adenocarcinoma, Fibroblast, Differentiation, Intestinal, Pancreatobiliary, Dysplastic, Cell proliferation, Cell invasion

\footnotetext{
* Correspondence: oliver.schilling@mol-med.uni-freiburg.de

Zon Weng Lai and Louisa Bolm share primary authorship. Ulrich Friedrich

Wellner and Peter Bronsert share senior authorship.

tEqual contributors

${ }^{1}$ Institute of Molecular Medicine and Cell Research, University of Freiburg,

Freiburg, Germany

${ }^{6}$ BIOSS Centre for Biological Signaling Studies, University of Freiburg,

Freiburg, Germany

Full list of author information is available at the end of the article
} 


\section{Background}

Posing a challenge to clinical and pathological assessment and diagnosis, ampullary adenocarcinoma (AMPAC) involves a wide range of histological differentiation as well as complex anatomic localization [1, 2]. Besides pancreatic, duodenal and distal bile duct adenocarcinomas, the World Health Organization classification system assesses AMPAC as one of the tumors of the periampullary region [3]. In contrast to pancreatic ductal adenocarcinoma (PDAC) clinicopathological studies indicate favorable survival prognosis, lower TNM stage and minor lymph node involvement in AMPAC $[1,4,5]$.

Histological differentiation of AMPAC has a strong impact on patient prognosis, as intestinal differentiation is associated with improved survival in comparison to the pancreatobiliary subtype $[6,7]$. In pathological routine of hematoxylin-eosin (H\&E) staining, difficulties often arise in regards to precise determination of either intestinal or pancreatobiliary type. In fact, histologic subtype is not a black-and-white scale but rather a continuum, in which tumors exist with mixed differentiation. This has led some authors to suggest a "forced binary approach" of subtype assessment [5]. For AMPAC, studies have previously shown that tumor expressing Cytokeratin 20 (KRT 20) correlate to intestinal type, while tumor lacking KRT 20 correlate to pancreatobiliary type [8], Caudal type homeobox 2 (CDX2) positive staining correlate to intestinal type $[9,10]$, and cytokeratin 7 (KRT 7) is expressed in the majority of pancreatobiliary and a minority of intestinal specimens $[11,12]$. Given that there is an existing demand for the development of further prognostic profiles of AMPAC differentiation [13, 14], KRT 20, CXD2 and KRT 7 qualify as potential immunohistochemical markers to determine survival prognosis $[6,15]$.

The cellular plasticity phenomenon of epithelialmesenchymal transition (EMT) has become an extensively studied biological concept to explain local tumor invasion and metastasis [16]. Recently, so-called tumor budding has been interpreted as a clinical correlation for partial epithelial-mesenchymal transition at the tumorstromal interface [17], and has also been previously shown to be a strong prognostic factor in AMPAC [18].

With recent large scale screening methods to demonstrate relevant correlations between the in vitro characteristics in of cell lines and clinical tumor biology [19-22], there has been increasing interests in cell line panels for the development of personalized treatment. However, only few cell lines from human ampullary cancer have been reported thus far, and to our best knowledge, no study has attempted to characterize these collectively [23-26]. Furthermore, the interaction between AMPAC cells of varying differentiation and stromal cells, such as cancer associated fibroblasts (CAF), has yet to be investigated. This study aims to characterize the five AMPAC cell lines with respect to subtype, EMT markers and as well as tumor-stroma interaction.

\section{Methods \\ Ethics, clinicopathologic assessment and immunohistochemistry}

Ethics board approval was obtained from the institutional ethics board of the University of Freiburg (ref 13/ 11). Written informed consent was obtained from patients for the use of tumor tissue for cell culture experiments. For retrospective histopathologic study, patients who underwent surgical treatment for AMPAC were identified from an in-house curated clinical database. A standard pathology protocol was applied for pancreatoduodenectomy specimens and clinicopathologic case review were performed as previously described [6]. Only cases with sufficient formalin-fixed and paraffinembedded tissue left for re-assessment were included for the study. Immunohistochemical staining for KRT7, KRT20, CDX2, ZEB1 and E-Cadherin was performed as previously described $[6,27]$. Tumor budding was quantified at the invasive front according to a protocol previously established from pancreatic cancer [27]. CAF activation grade was classified according to $\mathrm{Ha}$ et al [28] as high (immature stroma) or low (mature stroma). Mature tumor stroma was defined as tumor stroma including fibroblasts with small spindle cell morphology, a thin and wavy body-structure and a symmetric/parallel orientation. Immature tumor stroma included fibroblasts with plump spindle-shaped cell morphology, a prominent nucleus with prominent nucleoli and with randomly a spatial orientation. Tumor stroma was evaluated in two fields of twenty fold magnification. A value of more than $50 \%$ immature fibroblasts of all fibroblasts were was considered as immature tumor stroma phenotype.

\section{Clinical statistics and hierarchical clustering}

Data collection and statistical analyses were performed operating with IBM SPSS Version 21 (SPSS Inc, Chicago, IL) and MedCalc Version 14 software (Medcalc bvba, Ostend, Belgium). Precise scaling for the different variables were expressed as median (and range), categorical parameters (cross-tabulation and percentages), and survival data (Kaplan-Meier method). For statistical testing, Spearman rank correlation and log rank test were employed. For hierarchical clustering and generation of heat-map images, Multi Experiment Viewer (MEV, www.tm4.org) [29] was used. To generate MEV dataset, gene or antigen expression levels were expressed as relative values with the maximum level defined as $100 \%$, and samples were named according to tumor subtype (INT intestinal, PB pancreatobiliary, POOR poorly differentiated) or cell line. Upon loading to MEV, gene/row normalization and hierarchical clustering (HCL) was 
performed [30] and heat-map images of the HCL tree diagrams generated for visual interpretation.

Cell culture and treatment with CAF-conditioned medium Ampullary carcinoma cell lines (MDA-AMP7, AVC1, RCB1280, SNU478, and SNU869) were obtained from Prof. Frazier (MDA-AMP7, MD Anderson Cancer Center, Houston/Texas, USA) [23], Prof. Sorio (AVC1, Institute of Pathology, University of Verona, Italy) [26], the RIKEN Cell Bank (RCB1280, http://cell.brc.riken.jp/ en/rcb, Japan) and the Korean Cell Line Bank (SNU478 and SNU869, http://cellbank.snu.ac.kr/english/index.php, Seoul, South Korea) [31]. PANC1 cells were purchased from the American Type Culture Collection (ATCC, www.atcc.org). All cells were cultured at $37{ }^{\circ} \mathrm{C}$ in $5 \%$ CO2 atmosphere in DMEM high glucose medium with GlutamaX (Life Technologies \#10566-032) containing 10 \% FBS (Life Technologies Standard FBS \#10500-064).

Cancer associated fibroblasts (CAF) were isolated by Bachem's outgrowth method [32] from a human ampullary adenocarcinoma (pancreatobiliary subtype) resected by pancreatoduodenectomy, and cell type and purity assessed by morphology and immunofluescent staining for Vimentin and Pan-Cytokeratin as described [17]. CAFs were expanded in $75 \mathrm{~cm}^{2}$ cell culture flasks to $70 \%$ confluence and cryopreserved at $-80{ }^{\circ} \mathrm{C}$ in standard freezing medium containing DMSO. Only CAF up to passage six were used.

For generation of CAF conditioned medium (CAF$\mathrm{CM}), \mathrm{CAFs}$ were grown until $70 \%$ confluence, before switching to fresh medium (DMEM $10 \%$ FCS) and incubated for $72 \mathrm{~h}$. CAF-CM was then removed from the CAFs, centrifuged at $1000 \mathrm{rpm}$ for $5 \mathrm{~min}$, sterile filtered $(0.22 \mu \mathrm{m})$, and transferred to AMPAC cells, which were previously seeded in standard culture flasks for one day prior and washed with PBS. Fresh CAF-CM was added every three days. AMPAC cells were cultured in CAFconditioned medium for 5-7 days until $70 \%$ confluence and CAF-CM treated and control cells were harvested by cell scraper after three times rinsing with PBS, centrifuged and pelleted at $1000 \mathrm{rpm}$ for $5 \mathrm{~min}$.

\section{Gene expression analysis, cell invasion and growth assay} Immunofluorescence of cultured cells and real time PCR for measurement of mRNA expression was performed as previously described [17]. Primer sequences were Actin beta (ACTB, GCCCTGAGGCACTCTTCCA, TTGCGG ATGTCCACGTCA) E-Cadherin (CDH1, GTCCTGG GCAGAGTGAATTT, GACCAAGAAATGGATCTGTG G), Zinc finger E-box binding homeobox-1 (ZEB1, AAG AATTCACAGTGGAGAGAAGCCA, CGTTTCTTGCA GTTTGGGCATT), Caudal type homeobox 2 (CDX2, C TGGAGCTGGAGAAGGAGTTTC, ATTTTAACCTGC CTCTCAGAGAGC), Cytokeratin 7 (KRT7, TGCTG
AAGAAGGATGTGGATGCTGC, TCTGGGACTGCAG CTCTGTCAACT) and Cytokeratin 20 (KRT20, GCG ACTACAGTGCATATTACAGACAA, GCAGGACAC ACCGAGCATTT). Cultrex BME Cell Invasion Assay (Trevigen \#3465-096-K) was performed according to the manufacturer's instructions as described [33]. For assessment of CAF effect on AMPAC cell invasiveness, CAF were seeded in the lower chamber in standard culture medium and left until $70 \%$ confluent after 3-6 days, while control wells contained no CAFs. AMPAC cells were then seeded into the upper chamber wells in DMEM medium with $0.1 \%$ FBS and matrigel transmigration measured after three days. Cell growth was measured using 3-(4,5-dimethylthiazol-2-yl)-2,5-diphenyltetrazolium bromide (MTT) assay as described [33]. For growth inhibition, low-dose Gemcitabine 40nM (Eli Lilly Co, Indianapolis, USA) was added to the culture medium one day after seeding 1000 cells per well into 96 well standard culture plates, and cell growth quantified after three days of treatment. Herein the pancreatic cancer cell line PANC1 served as a Gemcitabineresistant model [34]. Similarly, all cells were incubated in Gemcitabine (100 nM, $1 \mu \mathrm{M}$ or $10 \mu \mathrm{M})$ one day after seeding 20000 cells per well into 24 well standard culture plates, and cell growth quantified after three days of treatment.

\section{Quantitative proteome comparison}

Cell pellets from harvesting were lysed using buffer containing $20 \mathrm{mM}$ Tris, $\mathrm{pH} 7.5,150 \mathrm{mM} \mathrm{NaCl}, 1 \%$ (v/v) Triton X-100 in the presence of protease inhibitors protease inhibitors $(5 \mathrm{mM}$ ethylene diamine tetraacetic acid, $10 \mu \mathrm{M}$ (2S, 3S)-trans-epoxysuccinyl-L-leucylamido-3methylbutane ethyl ester, $1 \mathrm{mM}$ phenylmethanesulfonyl fluoride). Lysates were kept on ice for $30 \mathrm{~min}$ with intermittent inverting to ensure proper lysis. Lysates were centrifuged for $10 \mathrm{~min}$ at $16000 \times \mathrm{g}$ and $4{ }^{\circ} \mathrm{C}$. Protein concentration of lysates was determined using bicinchoninic acid assay. Proteins were precipitated using icecold acetone and trypsinized (Worthington Biochemical Corp., Lakewood, NJ, USA). Cysteine residues were reduced and alkylated, followed by dimethylation of peptide N-termini and lysine residues. Samples from control treated cells were isotopically labeled using $40 \mathrm{mM}$ ${ }^{12} \mathrm{COH}_{2}$ formaldehyde (Sigma-Aldrich, Steinheim, Germany) while samples from fibroblast conditioned medium were isotopically labeled using $40 \mathrm{mM}^{13} \mathrm{COD}_{2}$ formaldehyle (Cambridge Isotope Laboratories, Andover, MA, USA) [35, 36], both in the presence of $40 \mathrm{mM}$ sodium cyanoborohydride for $16 \mathrm{~h}$ at room temperature. Excess formaldehyde was quenched using $20 \mathrm{mM}$ glycine. Samples were combined in a 1:1 (w/w) ratio manner and desalted using a reversed phase C18 Sep-Pak SPE column (Waters, Milford, MA, USA). Samples were 
subsequently fractionated using high performance liquid chromatography, coupled to a strong cation exchange column (PolyLC, Columbia, MD, USA). Buffer A con-

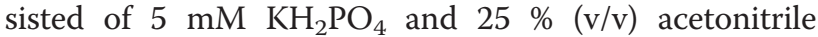
(pH 2.7), and buffer B consisted of $5 \mathrm{mM} \mathrm{KH}_{2} \mathrm{PO}, 1 \mathrm{M}$ $\mathrm{KCl}$, and $25 \%$ acetonitrile (pH 2.7). Peptides were eluted in a linear gradient with increasing concentration of buffer B. Resulting fractions were collected, desalted using self-packed C18 STAGE tips (Empore, St. Paul, MN, USA) [37], and analyzed by mass spectrometry.

\section{Mass spectrometry and data processing}

Samples were analyzed on an Orbitrap XL (Thermo Scientific, Bremen, Germany) or an Orbitrap Q-Exactive plus (Thermo Scientific) mass spectrometer. The Orbitrap XL was coupled to an Ultimate3000 micro pump (Thermo Scientific). Buffer A was $0.5 \%$ (v/v) acetic acid, buffer B $0.5 \%(\mathrm{v} / \mathrm{v})$ acetic acid in $80 \%$ acetonitrile (HPLC grade). Liquid phases were applied at a flow rate of $300 \mathrm{nl} / \mathrm{min}$ with an increasing gradient of organic solvent for peptide separation. Reprosil-Pur 120 ODS-3 (Dr. Maisch) was used to pack column tips of $75 \mu \mathrm{m}$ inner diameter and $11 \mathrm{~cm}$ length. The MS was operated in data dependent mode and each MS scan was followed by a maximum of five MS/MS scans. The Q-Exactive plus mass spectrometer was coupled to an Easy nanoLC 1000 (Thermo Scientific) with a flow rate of $300 \mathrm{nl} / \mathrm{min}$. Buffer A was $0.5 \%$ formic acid, and buffer B was $0.5 \%$ $(\mathrm{v} / \mathrm{v})$ formic acid in acetonitrile (water and acetonitrile were at least HPLC gradient grade quality). A gradient of increasing organic proportion was used for peptide separation (5-40\% (v/v) acetonitrile in $80 \mathrm{~min})$. The analytical column was an Acclaim PepMap column (Thermo Scientific), $2 \mu \mathrm{m}$ particle size, $100 \AA$ pore size, length $150 \mathrm{~mm}$, inner diameter $50 \mu \mathrm{m}$. The mass spectrometer operated in data dependent acquisition mode with a top ten method at a mass range of 300-2000 Da.

LC-MS/MS data were analyzed using X! Tandem (Version 2013.09.01) [38] in conjunction with PeptideProphet [39] using a $5 \%$ peptide false discovery rate and a decoy search strategy, and ProteinProphet [40] at a protein false discovery rate of $1 \%$. The protein database was composed of annotated human UniProt protein sequences (without isoforms, downloaded on on November 26, 2013 with 20,240 real protein entries), combined with a randomized and a reversed decoy database X! Tandem parameters included: precursor mass error of $\pm 10 \mathrm{ppm}$, fragment ion mass tolerance of $20 \mathrm{ppm}$ (Q-Exactive) or $0.4 \mathrm{Da}$ (Orbitrap XL), tryptic specificity with no missed cleavage, static residue modifications: cysteine carbamidomethylation $(+57.02 \mathrm{Da})$, as well as lysine and $\mathrm{N}$-terminal dimethylation $\left({ }^{12} \mathrm{COH}_{2}\right.$ formaldehyde, $+28.03 \mathrm{Da} ;{ }^{13} \mathrm{COD}_{2}$ formaldehyde, $+34.06 \mathrm{Da}$ ). For relative peptide and protein quantification, XPRESS [41] was used. Mass tolerance for quantification was $\pm 0.015 \mathrm{Da}$ (for Orbitrap XL), or \pm 20 ppm (for Q-Exactive Plus). Ratios of each dataset were calculated as treated cells over control. The mass spectrometry proteomics data have been deposited to the ProteomeXchange Consortium [42] via the PRIDE partner repository with the dataset identifier PXD002657 (username: reviewer66711@ebi.ac.uk password: TdyZ2Yle). XPRESS data was $\log _{2}$ transformed, resulting in foldchange values. Proteins were considered as being differentially regulated if the proteins are consistently expressed minimum three out of five cell lines with a fold-change value of greater than 0.58 (differential abundance equivalent to $50 \%$ ). The list of affected proteins was submitted to STRING database version 9.1 [43]. Predicted functional connections among proteins are based on the following criteria: neighborhood, co-expression, gene fusion, experiments, co-occurrence, databases and text-mining. QIAGEN's Ingenuity ${ }^{\circ}$ Pathway Analysis (IPA', QIAGEN Redwood City, www.qiagen.com/ingenuity) was further used to derive and visualize biological themes that were significantly associated to affected proteins identified from mass spectrometry analyses.

\section{Results}

\section{Clinical survival analysis and biologic correlation}

Clinicopathologic review resulted in the inclusion of $n=39$ patients (17 women, 22 men) treated by pancreatoduodenectomy for AMPAC from 2001 to 2011. Median tumor size was $20 \mathrm{~mm}$, about half of tumors were of $\mathrm{T} 1 / \mathrm{T} 2$ stage and $59 \%$ had locoregional lymph node metastasis, with a lymph node ratio of 0.10 or more in $44 \%$. Most tumors displayed low grading (78 \% G1 or G2), microscopic lymphangiosis was common (49\%), perineural invasion found in only $33 \%$, and hemangiosis rare $(5 \%)$. There were only three cases with positive surgical resection margin (Table 1).

Using a forced-binary approach [5], histopathological subtypes found were intestinal (46\%), pancreatobiliary (44 \%) and poorly differentiated (10\%). At a median follow-up of 27 months, only 13 patients had died and median survival was not reached, giving a mean survival estimate of 74 months. Patients with positive surgical margin status suffered poor prognosis (median survival eight months, $p=0.000$ ). Biological factors that showed significant prognostic impact $(p<0.05)$ include intestinal subtype, lymph node radio and lymphangiosis. Correlation analysis between these prognostic factors disclosed a negative correlation between intestinal subtype and lymph node ratio, and a positive correlation of lymphangiosis with lymph node ratio (Table 2).

To further assess the biology of the intestinal differentiation, immunohistochemical staining was performed for KRT 7, KRT 20 and CDX2 for confirmation of phenotype, 
Table 1 Baseline parameters

\begin{tabular}{|c|c|c|c|c|}
\hline Parameter & Condition & $\mathrm{n}$ or median & $\%$ or range & $p$-value \\
\hline \multicolumn{2}{|l|}{ n } & 39 & $100 \%$ & - \\
\hline \multicolumn{2}{|l|}{ Age (years) } & 64 & $36-84$ & $0.063^{\mathrm{a}}$ \\
\hline \multirow[t]{2}{*}{ Sex } & Female & 17 & $44 \%$ & 0.918 \\
\hline & Male & 22 & $56 \%$ & \\
\hline \multicolumn{2}{|c|}{ Death during follow-up } & 13 & $33 \%$ & - \\
\hline \multicolumn{2}{|c|}{ Follow-up (months) } & 27 & $1-116$ & - \\
\hline \multicolumn{2}{|c|}{ Tumor size (mm) } & 20 & $2-320$ & 0.497 \\
\hline \multirow[t]{2}{*}{ T stage } & $\mathrm{T} 1 / 2$ & 19 & $49 \%$ & 0.140 \\
\hline & $\mathrm{T} 3 / 4$ & 20 & $51 \%$ & \\
\hline \multicolumn{2}{|c|}{ Lymph node metastasis } & 23 & $59 \%$ & 0.112 \\
\hline \multicolumn{2}{|c|}{ Lymph node ratio $>=0.10$} & 17 & $44 \%$ & 0.003 \\
\hline \multicolumn{2}{|l|}{ Lymphangiosis } & 19 & $49 \%$ & 0.006 \\
\hline \multicolumn{2}{|l|}{ Hemangiosis } & 2 & $5 \%$ & 0.778 \\
\hline \multicolumn{2}{|c|}{ Perineural invasion } & 13 & $33 \%$ & 0.407 \\
\hline \multirow[t]{2}{*}{ Tumor grade } & G1-2 & 28 & $72 \%$ & 0.439 \\
\hline & G3-4 & 11 & $28 \%$ & \\
\hline \multicolumn{2}{|c|}{ Positive margin } & 3 & $8 \%$ & 0.000 \\
\hline \multirow[t]{3}{*}{ Subtype } & INT & 18 & $46 \%$ & $0.030^{\mathrm{b}}$ \\
\hline & PB & 17 & $44 \%$ & \\
\hline & POOR & 4 & $10 \%$ & \\
\hline
\end{tabular}

$p$ values derived from two-sided Logrank test. ${ }^{a}$ cutoff at median, ${ }^{b}$ test for INT vs non-INT subtype

Abbreviations: INT intestinal subtype, $P B$ pancreatobiliary subtype, $P O O R$ poorly differentiated adenocarcinoma

as well as E-Cadherin and ZEB1 for assessment of epithelial-mesenchymal transition (EMT) (Fig. 1). Tumor stroma was assessed by morphologic CAF activity grading. In agreement with previous reports, our results show high KRT7 and E-Cadherin expressions, low CDX2 and KRT20

Table 2 Correlation matrix for prognostic factors in ampullary adenocarcinoma

\begin{tabular}{|c|c|c|c|c|c|c|}
\hline & & INT & PB & LNR & L & $R$ \\
\hline \multirow[t]{2}{*}{ INT } & CC & & -0.81 & -0.59 & -0.18 & -0.27 \\
\hline & $p$ & & .000 & .000 & .267 & .100 \\
\hline \multirow[t]{2}{*}{ PB } & CC & -0.81 & & 0.48 & 0.07 & 0.33 \\
\hline & $p$ & .000 & & .002 & .653 & .041 \\
\hline \multirow[t]{2}{*}{ LNR } & CC & -0.59 & 0.48 & & 0.52 & 0.21 \\
\hline & $p$ & .000 & .002 & & .001 & .194 \\
\hline \multirow[t]{2}{*}{ L } & CC & -0.18 & 0.07 & 0.52 & & 0.30 \\
\hline & $p$ & .267 & .653 & .001 & & .067 \\
\hline \multirow[t]{2}{*}{$R$} & CC & -0.27 & 0.33 & 0.21 & 0.30 & \\
\hline & $p$ & .100 & .041 & .194 & .067 & \\
\hline
\end{tabular}

$\mathrm{CC}$ and $p$ values derived from two-sided Spearman rank correlation Abbreviations: CC correlation coefficient, INT intestinal subtype, $P B$ pancreatobiliary subtype, $L N R$ lymph node ratio, $L$ lymphangiosis, $R$ margin positive resection expressions, and occasional ZEB1 and Vimentin expressions in the non-intestinal subtypes (pancreatobiliary and poorly differentiated). In contrast to Vimentin, the variation in ZEB1 expression level were rather high. In addition, tumor budding and CAF grade are elevated in pancreatobiliary type cancers. Furthermore, intestinal type tumors showed significantly reduced ZEB1 expression in tumor cells, higher tumor budding at the invasive front as well as reduced CAF activation grade compared to nonintestinal tumors (Table 3) (Fig. 2a and b). This has led us to investigate the interaction between CAF and tumor cells in vitro to evaluate causality of these associations.

\section{Culture and characterization of ampullary cancer cell lines and $\mathrm{CAF}$}

CAFs were isolated from a human ampullary cancer explant using Bachem's outgrowth method [32]. Cell type and purity was confirmed by typical morphology using phase-contrast microscopy, in which strong vimentin expression and lack of Pan-Cytokeratin staining in immunofluorescence were observed (Fig. 3). Literature review revealed eight reported cell lines derived from AMPAC (Table 4): two cell lines were derived from distant metastases (MDA-AMP7 and RCB1280), one cell line from a poorly differentiated primary tumor with signet ring cell features (SNU478), and one from a moderately differentiated AMPAC arising in a villous adeoma (AVC1). Therefore most cell lines stem from tumors with aggressive biological features, leaving only one cell line derived from a well-differentiated AMPAC (SNU869). At present, no information on AMPAC subtype or patient follow-up has been reported. One cell line already ceased (UKEAC-99, personal communication with author), and the rest was obtained from the cell line banks or authors (see methods). Five of seven cell lines were successfully cultured in standard culture medium (DMEM $10 \%$ FCS) and are used for further experiments. Three cell lines (RCB1280, RCB1281, RCB1282) are derived from the same patient, indicating successful culture of one cell line from each reported patient.

The ampullary adenocarcinoma cell lines MDAAMP7, AVC1, RCB1280, SNU478 and SNU869 were grown in standard culture medium and expression of KRT7, KRT20, CDX2, E-Cadherin and ZEB1 mRNA was measured by real-time PCR. To investigate the heterogeneous expression pattern, we employed unsupervised hierarchical clustering for analysis. Results evidently indicate that three types of expression patterns (Fig. 4a): Cell lines MDA-AMP7, AVC1, RCB1280 displayed an undifferentiated mesenchymal-like expression pattern, characterized by strong expression of the EMT-inducer ZEB1 and low or lacking expression of E-Cadherin and subtype markers KRT7, KRT20 and CDX2. The SNU478 


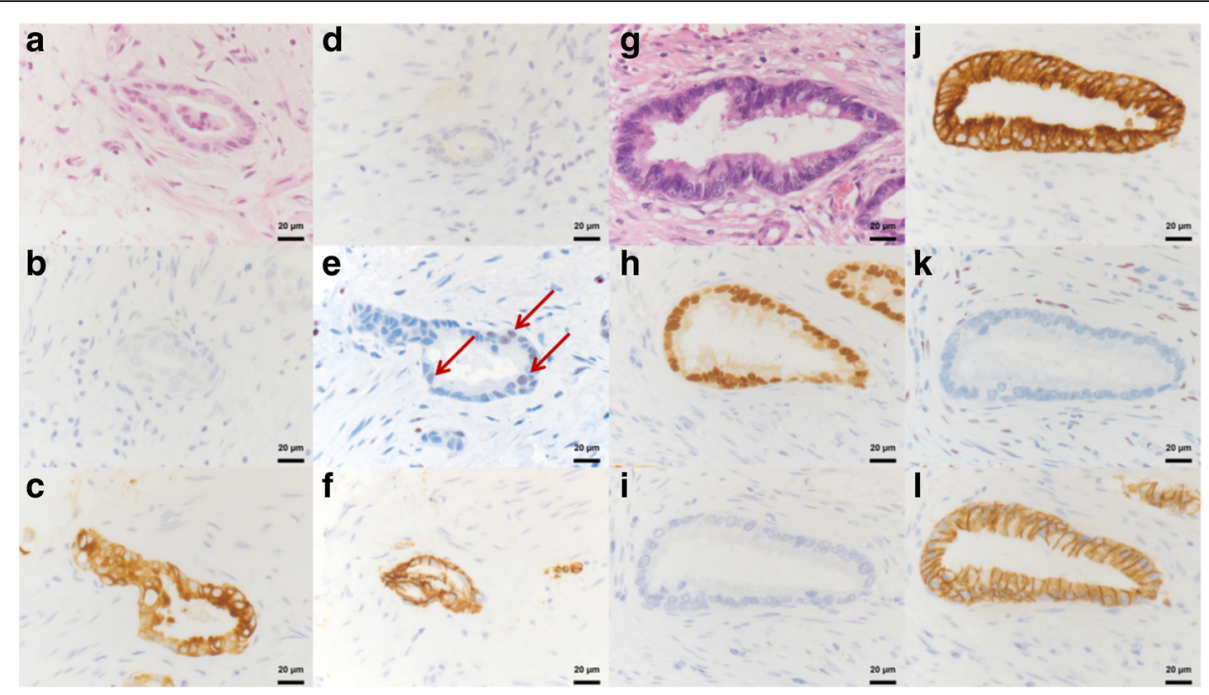

Fig. 1 Immunohistochemical staining of ampullary cancer. Subtype (a-d; $\mathbf{g}-\mathbf{j})$ and EMT (e\&f; k\&l) histomorphologoical and immunohistological analysis for the intestinal (a-f) and pancreatobiliary ( $\mathbf{g}-\mathbf{l})$ AMPAC subtype, taken at 40-fold magnification. HE (a\&g) staining representing the pancreaticobilliary (a) subtype with cuboidal formed columnar tumor cells and rounded nuclei, membranous KRT7 (c) positivity, CDX2 (b) and KRT20 (d) negativity and the intestinal type (g) with pseudostratified mucin producing glandular epithelium, elongated hyperchromatic and pseudostratified nuclei, nuclear CDX2 (h) and membranous KRT20 (j) positivity and KRT7 negativity (i). Nuclear ZEB1 expression (e, red arrows) is linked with a immunohistological membranous to cytoplasmatic Ecad shuttling. Contrary absent ZEB1 expression is immunohistological accompanied with membranous Ecad expression. Abbreviation: EMT Epithelial-Mesenchymal-Transition; AMPAC Ampullary Adenocarcinoma; HE Hematoxylin-Eosin, KRT Cytokeratin, CDX2 Caudal Type Homeobox 2, ZEB1 Zinc finger E-box binding homeobox 1, Ecad E-Cadherin

cells exhibited a pancreatobiliary-like expression pattern with strong KRT7 and low KRT20 and CDX2 expression, while the SNU869 cell line showed an intestinallike expression pattern with strong KRT20 and CDX2, but no KRT7 expression. The latter two cell lines also displayed no or weak expression of the EMT-inducer ZEB1. Interestingly, intestinal-like SNU869 cells is the only cell line to express high amounts of E-Cadherin.

To compare the gene expression pattern of cell lines to the expression pattern in the human AMPAC tumor samples, maximum gene expression was defined as $100 \%$ and relative expression values calculated on a linear scale for each gene. Upon analysis of the relative expression datasets of tumors and cell lines, unsupervised hierarchical clustering revealed two main clusters; intestinal type tumors and pancreatobiliary, respectively (Fig. 4b). Poorly differentiated tumors did not form a distinct cluster, but were found as a sub-cluster of the pancreatobiliary type tumor. Additionally, there was a minor cluster of apparently atypical expression pattern tumors, consisting of three morphologically intestinal-type and two poorly differentiated tumors and characterized by strong CDX2

Table 3 Tumor biologic factors correlating with the intestinal subtype

\begin{tabular}{|c|c|c|c|c|c|}
\hline \multirow[t]{2}{*}{ Parameter } & \multicolumn{3}{|l|}{ Subtype } & \multicolumn{2}{|c|}{ Correlation with INT } \\
\hline & $\overline{\text { INT }}$ & PB & POOR & $\overline{C C}$ & $p$ \\
\hline CK7 \% & $70(0-100)$ & $90(5-100)$ & $40(0-90)$ & -0.24 & 0.148 \\
\hline CK20 \% & $90(0-100)$ & $5(0-100)$ & $2.5(0-10)$ & 0.47 & 0.003 \\
\hline CDX2 \% & $90(20-100)$ & $10(0-80)$ & $45(0-100)$ & 0.69 & 0.000 \\
\hline ZEB1 \% & $0(0-2)$ & $0(0-16)$ & $2(0-3)$ & -0.32 & 0.046 \\
\hline VIM \% & $0(0-10)$ & $0(0-10)$ & $0(0-0)$ & 0.02 & 0.914 \\
\hline ECad \% & $100(50-100)$ & $100(75-100)$ & $75(50-100)$ & 0.03 & 0.869 \\
\hline Budding & $8(0-35)$ & $15(2-46)$ & $43(6-66)$ & -0.46 & 0.003 \\
\hline CAF & $1(0-2)$ & $2(0-2)$ & $0.5(0-1)$ & -0.34 & 0.035 \\
\hline
\end{tabular}

$\mathrm{CC}$ and $p$ values derived from two-sided Spearman rank correlation. \% expression in percentage of tumor cells, Tumor budding measured as number of tumor buds per HPF (high power field)

Abbreviations: INT intestinal, PB pancreatobiliary, POOR poorly differentiated, CC correlation coefficient, KRT cytokeratin staining, CDX2 caudal type homeobox 2 , ZEB1 zinc finger and homeobox 1, ECad E-Cadherin, CAF cancer associated fibroblast activation 


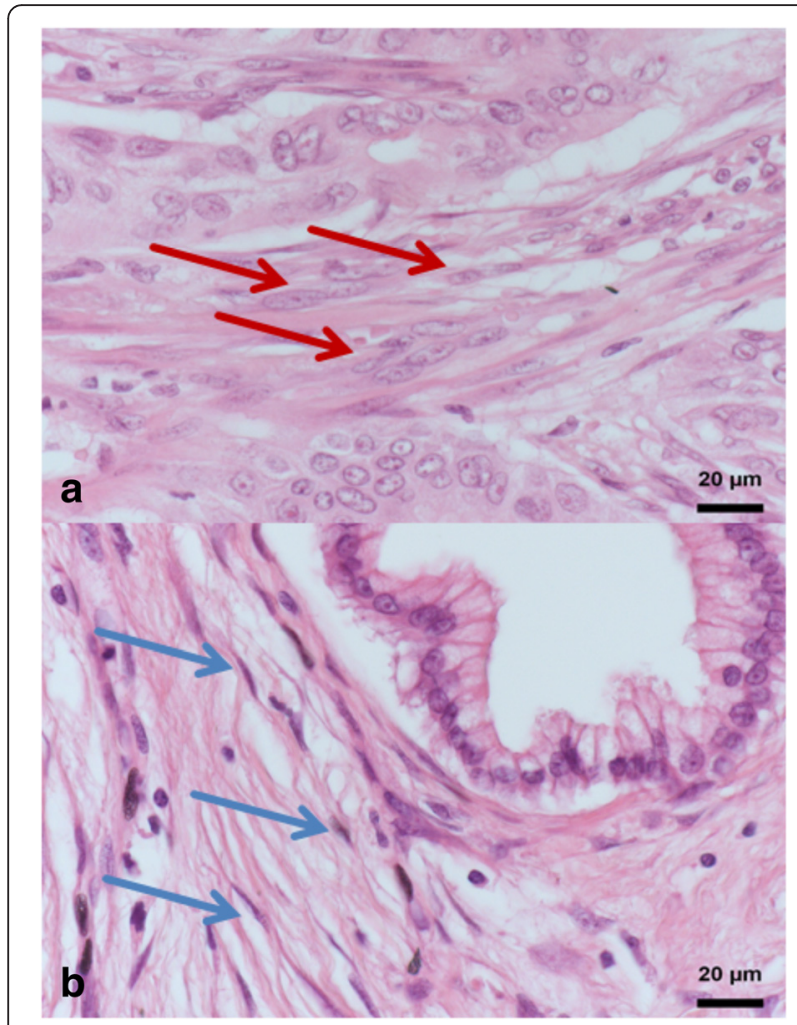

Fig. 2 CAF activation grade in AMPAC, represented by HE staining taken at 40-fold magnification. a Immature tumor stroma with plump spindleshaped cell morphology, prominent nucleus, prominent nucleoli (red arrow) and with randomly a spatial orientation. b Mature tumor stroma with small spindle cell morphology, a thin and wavy body-structure (blue arrow) and a symmetric/parallel orientation. Abbreviation: AMPAC = Ampullary Adenocarcinoma; $\mathrm{HE}=$ Hematoxylin-Eosin

expression but no KRT20 or KRT2 expression. In regards to the cell lines, the mesenchymal-like cell lines MDAAMP7, AVC1 and RCB1280 clustered together with a poorly differentiated tumor in the pancreatobiliary cluster, while being closely related to the pancreatobiliary-like
SNU478 cell line together with a pancreatobiliary tumor. The intestinal-like cell line SNU869 however was found within the cluster for intestinal tumor, a clear separation from the other cell lines.

\section{In vitro growth, invasion and chemosensitivity}

Following above-mentioned observations, we hypothesized that cell invasion in vitro would reflect the clinical tumor aggressiveness. Baseline cell growth assessed by MTT assay demonstrated that SNU869 cells were the slowest growing among all AMPAC cell lines (Fig. 5a). Also the matrigel transmigration assay confirmed that the mesenchymal-like cell lines had the strongest invasion, followed by the pancreatobiliary-like SNU 478, while the intestinal-like SNU869 cells were far less invasive (Fig. 6a). Low-dose Gemcitabine, a commonly used drug for adjuvant AMPAC treatment [44], significantly inhibited the growth of the mesenchymal- and pancreatobiliary-like AMPAC cells, but not of the intestinal-like cell line, where cell growth was even slightly increased after three days. As a control, growth of PANC1, a pancreatic cancer cell line known to be Gemcitabine resistant [34], was not changed (Fig. 5b). Cell viability of all cell lines in response to higher concentrations of Gemcitabine is also highlighted (Fig. 5d).

\section{Effects of CAF-conditioned medium on ampullary cancer cells}

Given the clinical association of high CAF activation grade in the more aggressive tumors with pancreatobiliary differentiation and EMT features, we further hypothesized that CAF could induce EMT and invasion, as well as subtype shift in cancer cells. To examine the paracrine effect of CAF, ampullary cancer cells were treated with conditioned medium from CAF (CAF-CM) and subjected to growth assay as well as matrigel transmigration assay with CAFs serving as attractant (Fig. 6b and c).

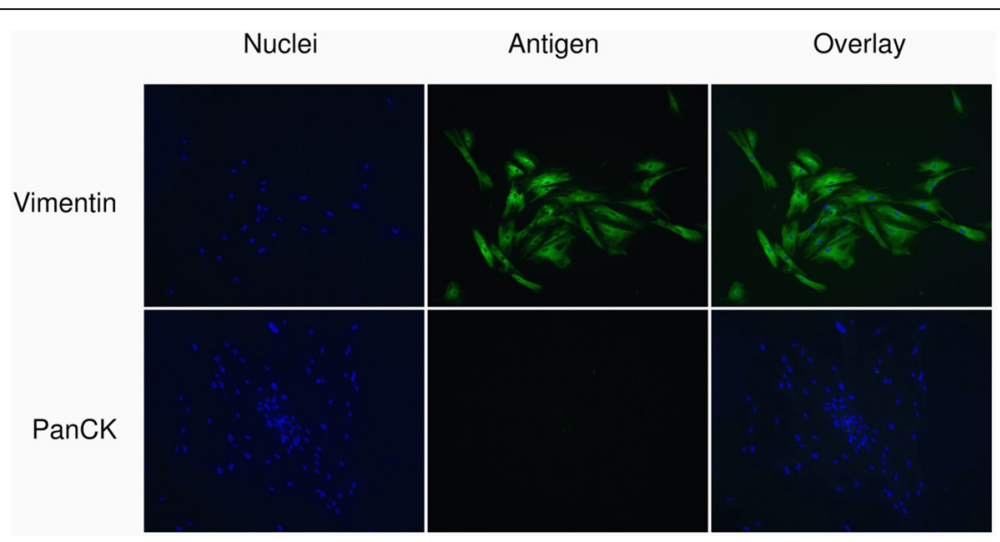

Fig. 3 Cancer associated fibroblasts isolated from ampullary cancer. Cancer associated fibroblasts (CAF) were isolated from human ampullary cancer by the outgrowth method. Immunofluorescent staining confirms strong expression of Vimentin (VIM) and typical spindle-like morphology, as well as lack of Pan-Cytokeratin (PanCK) staining 
Table 4 Ampullary cancer cell lines reported in the literature

\begin{tabular}{|c|c|c|c|c|c|c|c|c|}
\hline Cell line & $\begin{array}{l}\text { Primary } \\
\text { tumor }\end{array}$ & $\begin{array}{l}\text { Cell line } \\
\text { derived from }\end{array}$ & $\begin{array}{l}\text { Histopathology/ } \\
\text { differentiation }\end{array}$ & $\begin{array}{l}\text { TNM } \\
\text { stage }\end{array}$ & $\begin{array}{l}\text { Kras } \\
\text { status }\end{array}$ & $\begin{array}{l}\text { Further } \\
\text { characterization }\end{array}$ & Patient follow-up & Reference \\
\hline \multicolumn{9}{|c|}{ Cell lines successfully grown in standard culture medium } \\
\hline $\begin{array}{l}\text { MDA- } \\
\text { AMP7 }\end{array}$ & AMPAC & $\begin{array}{l}\text { Peritoneal } \\
\text { metastasis }\end{array}$ & Not reported & rpM1 & $\begin{array}{l}\text { Not } \\
\text { reported }\end{array}$ & $\begin{array}{l}\text { Aneuploidy and } \\
\text { structural } \\
\text { chromosomal } \\
\text { mutations }\end{array}$ & $\begin{array}{l}\text { Peritoneal metastases } \\
\text { occurred } 9 \text { months after } \\
\text { resection of primary tumor }\end{array}$ & $\begin{array}{l}\text { Frazier et al. } \\
\text { (Frazier et al. } \\
\text { 1992) }\end{array}$ \\
\hline AVC1 & AMPAC & $\begin{array}{l}\text { Primary } \\
\text { tumor }\end{array}$ & $\begin{array}{l}\text { Moderately differentiated, } \\
\text { arising from villous } \\
\text { ampullary adenoma }\end{array}$ & $\begin{array}{l}\text { PT1NO } \\
\text { CM0 }\end{array}$ & Mutated & $\begin{array}{l}\text { Tumorigenic in mice, } \\
\text { moderate } \\
\text { Gemcitabine } \\
\text { sensitivity }\end{array}$ & Perioperative death & $\begin{array}{l}\text { Sorio et al. } \\
\text { (Sorio et al. } \\
\text { 2004) }\end{array}$ \\
\hline RCB1280 & AMPAC & $\begin{array}{l}\text { Liver } \\
\text { metastasis }\end{array}$ & not reported & $\begin{array}{l}\text { not } \\
\text { reported }\end{array}$ & $\begin{array}{l}\text { Not } \\
\text { reported }\end{array}$ & $\begin{array}{l}\text { structural } \\
\text { chromosomal } \\
\text { mutations }\end{array}$ & Not reported & $\mathrm{RCB}$ \\
\hline SNU478 & AMPAC & $\begin{array}{l}\text { Primary } \\
\text { tumor }\end{array}$ & $\begin{array}{l}\text { poorly differentiated with } \\
\text { signet ring cell features }\end{array}$ & $\begin{array}{l}\text { pNo } \\
(0 / 5)\end{array}$ & $\begin{array}{l}\text { Wild } \\
\text { type }\end{array}$ & $\begin{array}{l}\text { E-Cadherin wild type } \\
\text { but methylated }\end{array}$ & Not reported & $\begin{array}{l}\text { Ku et al. } \\
\text { (Ku et al. 2002) }\end{array}$ \\
\hline SNU869 & AMPAC & $\begin{array}{l}\text { Primary } \\
\text { tumor }\end{array}$ & $\begin{array}{l}\text { well differentiated with } \\
\text { focal papillary } \\
\text { differentiation }\end{array}$ & $\begin{array}{l}\mathrm{pN} 1 \\
(5 / 10)\end{array}$ & $\begin{array}{l}\text { Wild } \\
\text { type }\end{array}$ & $\begin{array}{l}\text { E-Cadherin wild type } \\
\text { and expressed }\end{array}$ & Not reported & $\begin{array}{l}\text { Ku et al. } \\
\text { (Ku et al. 2002) }\end{array}$ \\
\hline \multicolumn{9}{|c|}{ Other cell lines reported } \\
\hline $\begin{array}{l}\text { UKEAC- } \\
99\end{array}$ & AMPAC & $\begin{array}{l}\text { Primary } \\
\text { tumor }\end{array}$ & \multicolumn{5}{|c|}{ cell line discarded (personal communication with authors) } & $\begin{array}{l}\text { Peiper et al. } \\
\text { (Peiper et al. } \\
\text { 2003) }\end{array}$ \\
\hline RCB1281 & AMPAC & $\begin{array}{l}\text { Peritoneal } \\
\text { metastasis }\end{array}$ & \multirow{2}{*}{\multicolumn{5}{|c|}{ cell line derived from same patient as RCB1280 }} & $\mathrm{RCB}$ \\
\hline RCB1282 & AMPAC & $\begin{array}{l}\text { Lymph node } \\
\text { metastasus }\end{array}$ & & & & & & $\mathrm{RCB}$ \\
\hline
\end{tabular}

Abbreviations: AMPAC ampullary adenocarcinoma, RCB RIKEN Bioresource Center Cell Bank http://cell.brc.riken.jp/en/

In the intestinal-like cell line SNU869, ZEB1 levels remained unchanged but E-Cadherin expression levels were reduced by approximately $50 \%$, while cell growth and invasion increased by about $50 \%$ with CAF-CM treatment (Figs. $5 \mathrm{~b}$ and $6 \mathrm{~b}$ ). The pancreatobiliary-like cell line SNU478 did not express significant changes in level of ZEB1 or E-Cadherin. However, a decrease of matrigel transmigration and no change in growth (Figs. 5b and 6b) were observed in SNU478 cells. Regarding the expression of the subtype marker genes, a
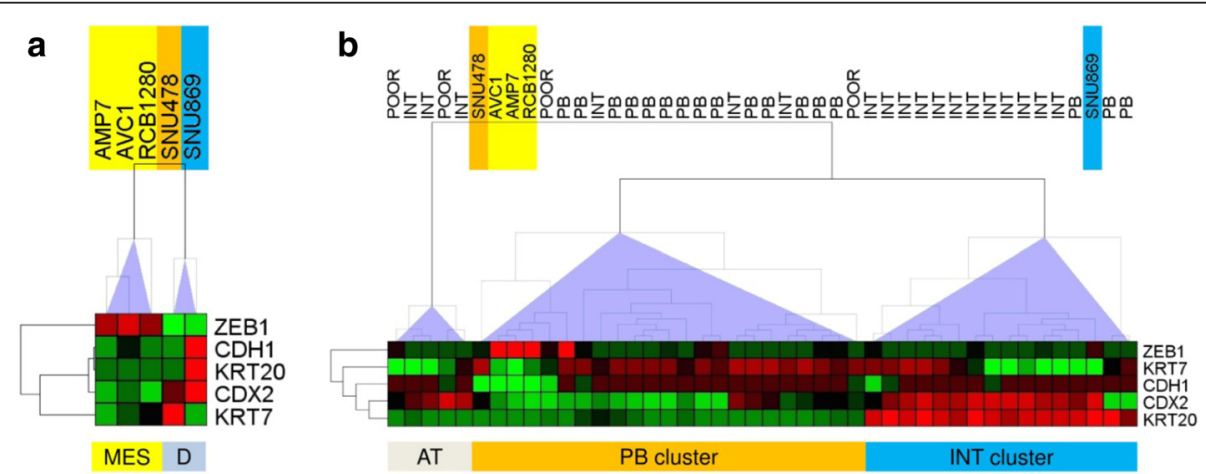

Fig. 4 Heatmaps and hierarchical clustering trees of ampullary cancer cell lines and tumors. Relative expression values of EMT (ZEB1, CDH1) and subtype marker genes (KRT7, KRT20, CDX2) were calculated by linear scaling, with maximum expression in cell lines/tumors defined as $100 \%$ and subjected to hierarchical clustering (HCL). a HCL tree of the cell lines discloses an mesenchymal-like (MES) and a differentiated (D) cluster of cell lines. MES cells show weak or no expression of subtype marker genes but strong ZEB1 and low E-Cadherin (CDH1) expression. One differentiated cell line displays pancreatobiliary-like (SNU478, orange), the other an intestinal-like marker gene expression pattern (SNU869, blue). b HCL tree of tumors and cell lines results in separation of an intestinal (INT), pancreatobiliary (PB) and atypical (AT) cluster. The cell lines are found separated to the PB and INT clusters. For further details see text. Abbreviations: EMT epithelial-mesenchymal transition, ZEB1 zinc finger E-box binding homeobox 1, $\mathrm{CDH1}$ Cadherin 1 = E-Cadherin, KRT Cytokeratin, CDX2 Caudal type homeobox 2, POOR poorly differentiated 


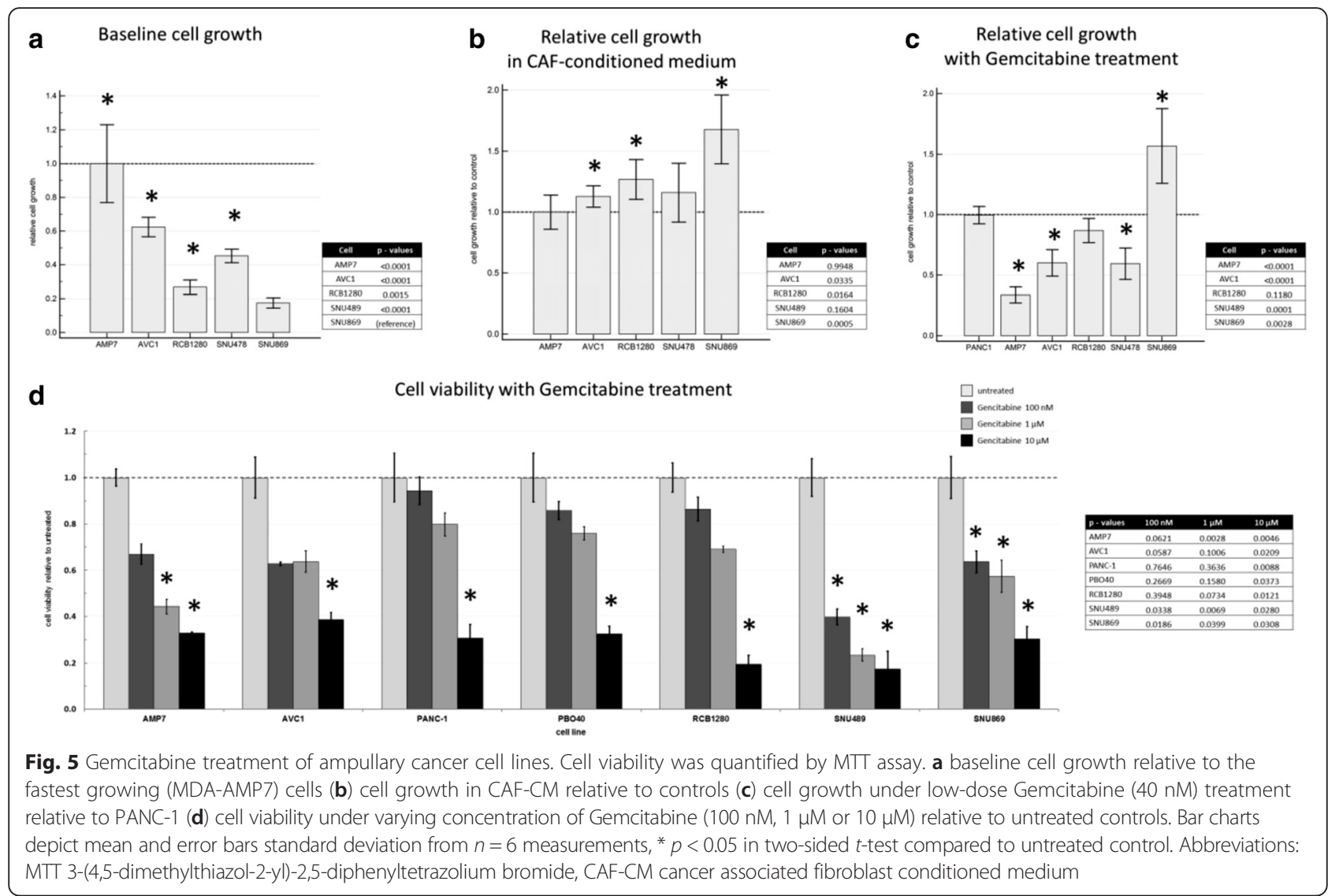

marked decrease of KRT20 expression and small but significant decrease in CDX2 expression was observed in the intestinal-like SNU869 cells, while KRT7 and CDX2 expression increased in the pancreatobiliary-like SNU478 cells (Fig. 6b).

Cell growth was slightly enhanced by CAF-CM in the mesenchymal-like cell lines except for the already fastgrowing MDA-AMP7 (Fig. 5a and b). Among the mesenchymal-like cell lines, AVC1 was the only cell line expressing measurable amounts of E-Cadherin. Consistent with EMT process, both ZEB1 expression and cell invasiveness were increased while E-Cadherin expression decreased with CAF-CM treatment (Fig. 6c). E-Cadherin was not expressed in the other two mesenchymal-like cell lines, and the high basal ZEB1 expression levels increased in RCB1280 cells but decreased in MDA-AMP7 cells. Nevertheless, matrigel transmigration were increased in MDA-AMP7 cells. RCB1280, as the most invasive of the five cell lines, did not further increase its matrigel transmigration with CAF-CM treatment (Fig. 6c). Regarding subtype markers among the mesenchymal-like cells, only CDX2 was expressed to a relevant but low degree in MDA-AMP7 cells, and further decreased with CAF-CM treatment (Fig. 6c).
Proteomic analysis of CAF-conditioned medium effect on ampullary cancer cells

To investigate the influence of CAF on the AMPAC cancer cell proteome, we performed quantitative shotgun proteomics of AMPAC cells treated with CAF-CM versus controls under standard culture conditions, respectively. Quantitative proteome comparison was performed for cell lysates of all five AMPAC cell lines. Stable isotope labeling with either ${ }^{12} \mathrm{COH}_{2}$ formaldehyde (light) or ${ }^{13} \mathrm{COD}_{2}$ formaldehyde (heavy) was used for relative quantitation.

LC-MS/MS analysis identified 3258 proteins in MDA-AMP7, 3007 proteins in AVC1, 2207 proteins in RCB1280, 3139 proteins in SNU487 and 4376 proteins in SNU869. The fold-change values (Fc-values, $\log _{2}$ of CAF-treated/untreated ratio) show a nearnormal distribution for all five replicates comparing CAF-conditioned medium treated and non-treated cells (Fig. 7a). These findings indicate the majority of proteins not being affected in abundance upon cultivation in CAF-conditioned medium. Furthermore, there is a moderate level of correlation between the Fc-values of the MDA-AMP7, AVC1, RCB1280 and SNU487 (Fig. 7b) indicating a comparable reaction in proteome composition of these cell lines to cultivation in CAF-conditioned 
a

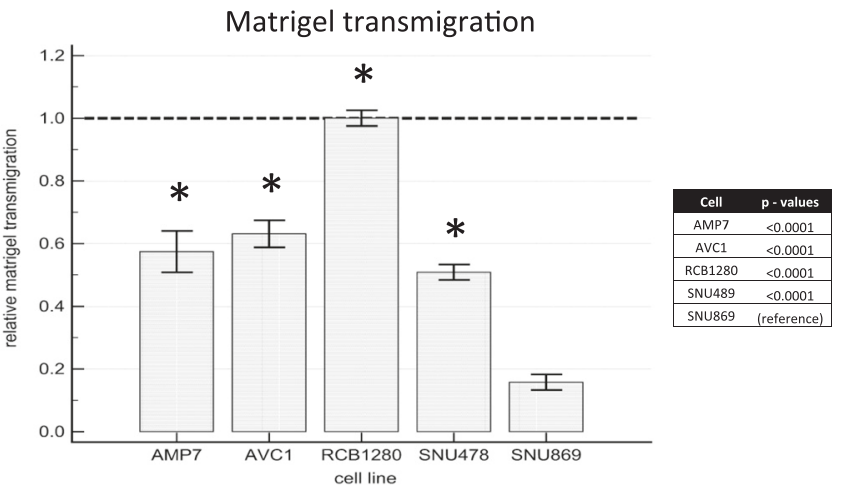

b

CAF-conditioned medium

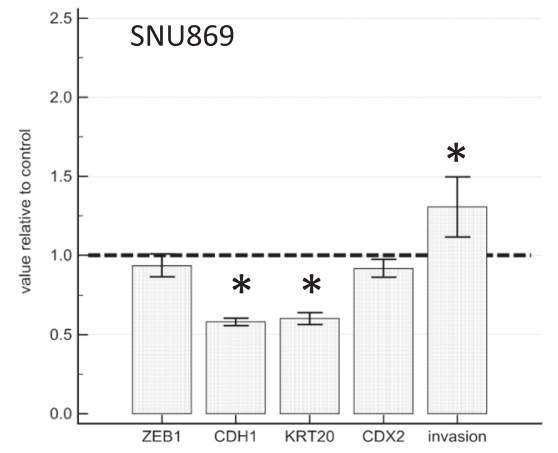

SNU478

C

CAF-conditioned medium
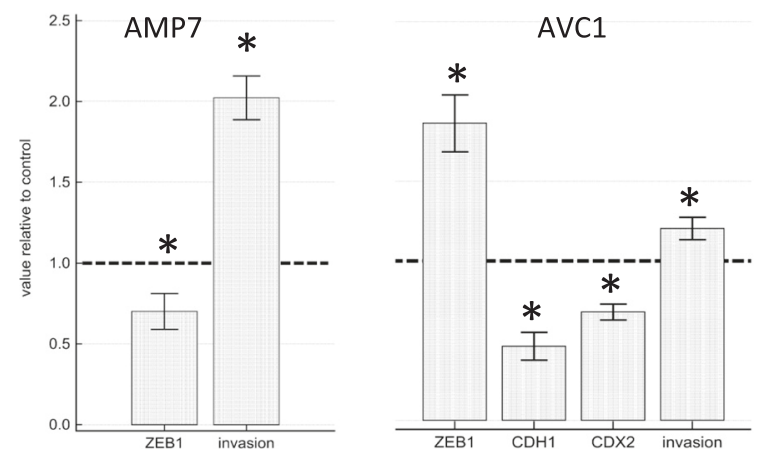

RCB1280
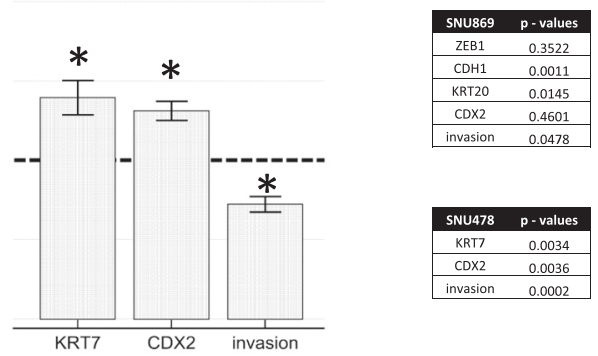

\begin{tabular}{ll}
$\mathrm{CDX2}$ & 0.0036 \\
\hline
\end{tabular}

Fig. 6 Cell invasion and gene expression changes in ampullary cancer cell lines treated with CAF conditioned medium. Cell invasion was quantified by matrigel transmigration assay and mRNA expression by real time PCR. a baseline matrigel transmigration relative to most invasive cell line RCB1280. b effect of CAF-CM on intestinal-like cell line SNU869 and pancreatobiliary-like cell line SNU478. c effect of CAF-CM on mesenchymal-like cell lines MDA-AMP7, AVC1 and RCB1280. Diagrams depict mean and error bars standard deviation from $n=4$ measurements, ${ }^{*} p<0.05$ in two-sided t-test compared to untreated control. Abbreviations: AMP7 MDA-AMP7, CAF-CM cancer associated fibroblast conditioned medium, ZEB1 zinc finger E-box binding homeobox 1, CDH1 Cadherin 1 = E-Cadherin, KRT Cytokeratin, CDX2 Caudal type homeobox 2

medium. Consequently, an overlap of 1493 proteins was identified among these four AMPAC cell lines (Fig. 7c). Partially incomplete overlap of proteome coverage is an intrinsic characteristic of mass spectrometry-based proteomics [45]. On the other hand, the Fc-values of the SNU869 cell line lack appreciable correlation to any of the other cell lines; suggesting a different rearrangement of proteome composition upon cultivation in CAFconditioned medium.
Proteins were considered as being differentially abundant upon cultivation in CAF-conditioned medium if the corresponding $\mathrm{Fc}$-value ( $\log _{2}$ of heavy:light ratio) is either greater than 0.58 or less than -0.58 , corresponding to a change in abundance exceeding $50 \%$. Mass spectrometry analysis showed that 1184 proteins were significantly affected in MDA-AMP7; 1323 in AVC1; 876 in RCB1280; 1603 in SNU487; and 745 in SNU869. A total of 345 proteins were commonly affected in these 

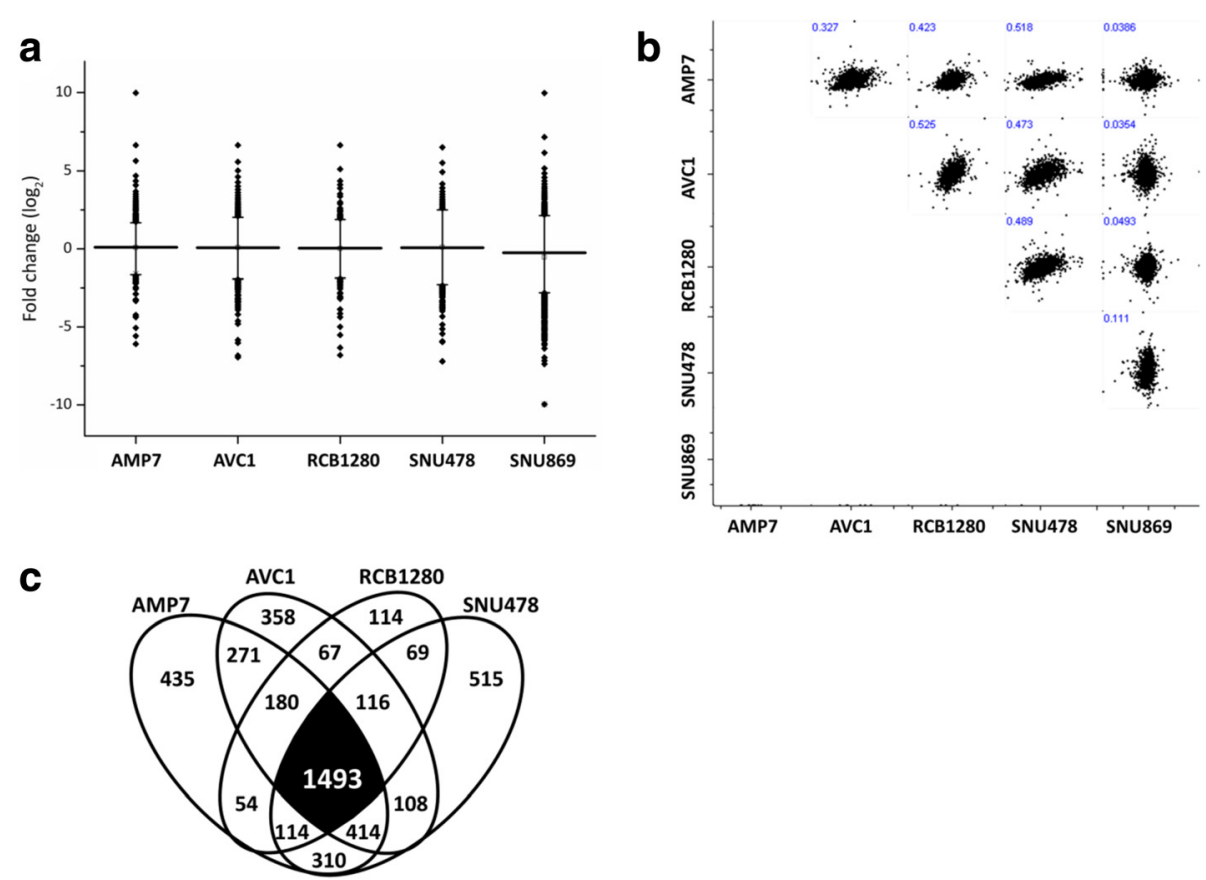

Fig. 7 Distribution of identified proteins in AMPAC cells cultivated in CAF conditioned medium. a Geometric mean (horizontal bar) of fold change values ( $\log _{2}$ of CAF-treated/control) of proteins from each AMPAC cell line comparing the CAF conditioned medium treatment or control. b Fold change correlation of all quantified proteins between different AMPAC cell lines treated with CAF-conditioned medium. c Venn diagram showing the overlap of proteins identified in individual AMPAC cell line upon cultivation with CAF conditioned medium or control

four AMPAC cell lines (MDA-AMP7, AVC1, RCB1280 and SNU487) $(p<0.10$, two-tailed $t$-test). Further 87 proteins were commonly affected in three cell lines with adequate correlation $(p<0.10$, two-tailed $t$-test). Collectively, a total of 432 proteins were differentially affected more than two-fold in at least three cell lines $(n \geq 3)$; 208 up-regulated $\left(\log _{2}\right.$ ratio $>0.58, p<0.10$, two-tailed $t$-test), and 224 down-regulated $\left(\log _{2}\right.$ ratio $>0.58$, $p<0.10$, two-tailed $t$-test). Additional data is listed in Additional file 1: Tables S1 and S2.

\section{Ingenuity pathway analysis of CAF-conditioned medium effects on ampullary cancer cells}

Ingenuity pathway analysis was used to elucidate biological themes being induced or repressed in AMPAC cells upon cultivation in CAF-conditioned medium. Comparison of the expression of all affected proteins (with pre-defined $\log _{2}$ cut-off value at \pm 0.5 ) revealed that several pathways including cellular proliferation and metabolism, cell death, and protein synthesis were significantly affected ( $p$-value $<0.01) \quad$ (Fig. 8a). Hierarchical clustering of all proteins identified in each AMPAC cell lines, based on activation $z$-score, showed similar likelihood of regulating proteins (based on a statistically significant pattern match of up- and down-regulation of biological processes) between the mesenchymal-like cell lines MDAAMP7, AVC1, RCB1280 and the pancreatobiliary-like
SNU487. In contrast, the more intestinal SNU869 showed regulation in the opposite manner in many identified biological themes.

The twenty most relevant biological themes affecting tumorigenesis and cancer progression of AMPAC cells upon the treatment with fibroblast conditioned medium are illustrated in Fig. 8b. Some of these biological processes include (a) positive regulation in cellular growth and proliferation, as well as infection and proliferation of tumor cell lines; and (b) negative regulation in tumor cell death and apoptosis. Many of these biological networks and pathways were also identified in Gene Ontology (GO) enrichment analysis. Gene Ontology (GO) enrichment analysis within the AMPAC subset of four (mesenchymal- and pancreatobiliary-like) cell lines (MDA-AMP7, AVC1, RCB1280 and SNU487) showed that 208 up-regulated proteins were mainly enriched in mRNA metabolism, intracellular transport and activation of the cytoskeleton (Table 5). STRING protein-protein interactions and KEGG pathway enrichment analyses showed the majority of these proteins being involved in cellular motility, RNA transport and organization of ribosomal proteins (Fig. 9a). For SNU869, a total of 432 up-regulated proteins were mostly enriched in membrane and cellular component organization, as well as in metabolic processes (Table 6). For down-regulated proteins within the same subset of the four cell lines, GO enrichment analysis showed 

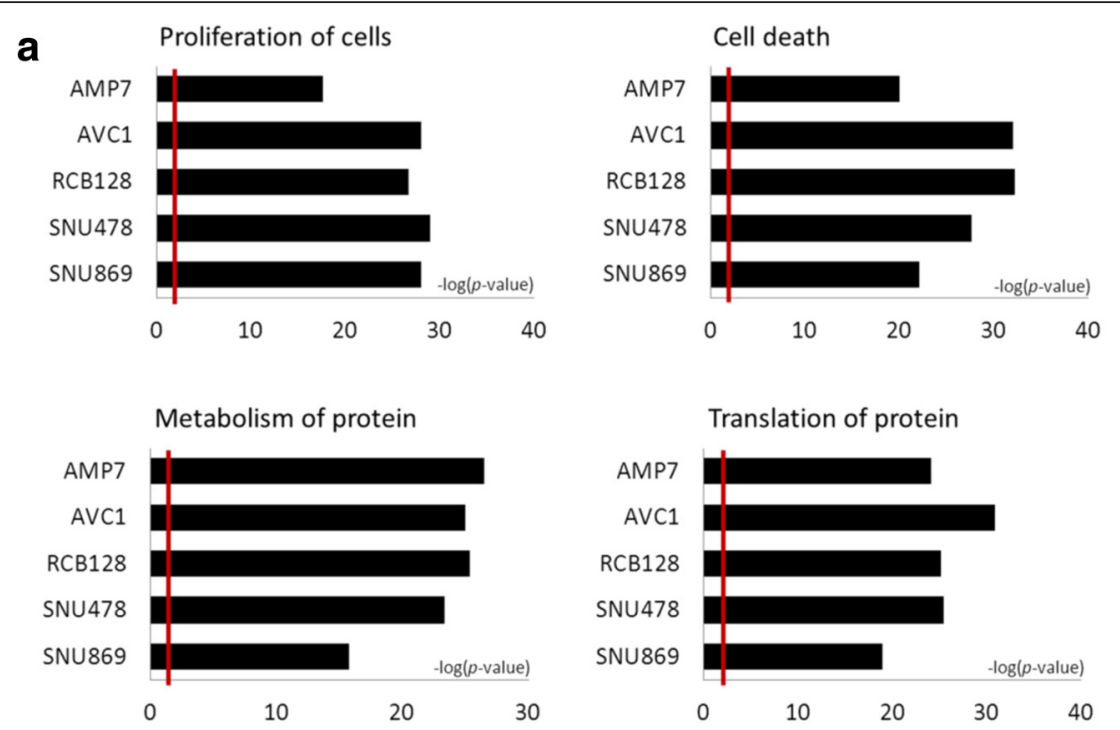

b

- threshold $(p<0.01)$

\begin{tabular}{|c|c|c|c|c|c|}
\hline Diseases and Bio Functions & AMP7 & AVC1 & RCB1280 & SNU478 & SNU869 \\
\hline infection of tumor cell lines & 2.27 & 1.72 & 1.81 & 0.99 & -5.75 \\
\hline cell viability of tumor cell lines & 2.20 & 1.55 & 1.25 & 1.94 & -4.23 \\
\hline cell viability & 3.11 & 2.42 & 2.32 & 1.34 & -3.83 \\
\hline cell survival & 3.71 & 3.06 & 2.60 & 1.62 & -3.82 \\
\hline proliferation of tumor cell lines & 3.59 & 2.25 & 1.08 & 3.12 & -2.57 \\
\hline proliferation of cells & 3.49 & 3.62 & 1.29 & 4.48 & -2.82 \\
\hline beta-oxidation of fatty acid & -1.18 & -1.96 & -1.61 & -0.56 & -1.81 \\
\hline cell death & -1.89 & -2.90 & -2.03 & -1.21 & 1.74 \\
\hline apoptosis & -1.85 & -3.30 & -1.95 & -0.51 & 1.15 \\
\hline translation of mRNA & -2.89 & -1.91 & -2.36 & -2.21 & 0.47 \\
\hline translation of RNA & -2.89 & -1.91 & -2.36 & -2.21 & 0.47 \\
\hline cell death of tumor cell lines & -2.23 & -3.04 & -3.04 & -3.26 & 0.13 \\
\hline necrosis & -1.63 & -2.45 & -1.96 & -2.20 & 0.44 \\
\hline apoptosis of tumor cell lines & -1.17 & -2.84 & -2.66 & -2.43 & 0.27 \\
\hline Growth Failure & -1.78 & -0.67 & 0.63 & -0.40 & 3.14 \\
\hline initiation of translation of protein & -1.52 & -1.13 & -0.24 & -0.37 & 2.04 \\
\hline expression of mRNA & -1.91 & -0.74 & -0.81 & -1.51 & 0.49 \\
\hline translation of protein & -1.01 & 0.37 & -0.27 & -0.32 & 0.53 \\
\hline expression of protein & -1.55 & 0.45 & -0.43 & -0.60 & 0.67 \\
\hline metabolism of amino acids & -0.60 & -2.18 & & -0.37 & -2.37 \\
\hline
\end{tabular}

Fig. 8 Bioinformatics analysis of quantified proteins by ingenuity pathway analysis. a Patho-physiological pathways and processes of proteins from AMPAC cell lines following treatment with CAF-conditioned medium or control. The threshold denotes statistical significance at $p<0.01$. b Hierarchical clustering based on activation z-score, showing likelihood of regulating proteins based on a statistically significant pattern match of up- and down-regulation of biological processes

that the 224 proteins were mainly involved in metabolic processes and phosphorylation (Table 5). STRING analysis and KEGG pathway enrichment analyses grouped these proteins into two main clusters; oxidative metabolism and phosphorylation, and amino acid and lipid metabolism (Fig. 9b). On contrary, 314 proteins were down-regulated in SNU869, which mainly involved in protein translation and peptide biosynthetic processes (Table 6).

\section{Discussion}

AMPAC is a relatively rare tumor comprising about 15-20\% of all adenocarcinomas resected by pancreatoduodenectomy $[6,46-48]$. The most important prognostic factors reported in the literature include surgical margin, lymph node metastasis and intestinal differentiation. The latter has been highlighted as a decisive parameter for clinical prognosis. Its tumor biology is less aggressive and postulated to be more related to colorectal cancer [49]. Therefore, suggested analogous therapy such as liver metastasis resection as well as chemotherapy regimens used for colorectal cancer might be indicative for intestinal AMPAC [50-52]. Despite the growing number of cell lines and increasing relevance of cell line based high-throughput screening methods $[21,22]$, establishment of ampullary cancer cell lines has only been limited [23-26]. Moreover, in vitro experimental data on AMPAC is absent. Hence, our aim 
Table 5 Gene Ontology (GO) functional enrichment analysis regulated proteins in ampullary cancer cells MDA-AMP7, AVC1, RCB1280 and SNU487

\begin{tabular}{lll}
\hline GO terms of up-regulated proteins & Count & FDR \\
GO:0065007 Biological regulation & 93 & $1.41 \mathrm{E}-02$ \\
GO:0071840 Cellular component & 67 & $2.08 \mathrm{E}-06$ \\
organization or biogenesis & & \\
GO:0051179 Localization & 54 & $5.18 \mathrm{E}-04$ \\
GO:0016071 mRNA metabolic process & 42 & $9.87 \mathrm{E}-23$ \\
GO:0032268 Regulation of cellular & 44 & $5.73 \mathrm{E}-11$ \\
protein metabolic process & & \\
GO:0050896 Response to stimulus & 75 & $1.09 \mathrm{E}-02$ \\
& & \\
GO terms of down-regulated proteins & Count & FDR \\
GO:0008152 Metabolic process & 98 & $9.97 \mathrm{E}-04$ \\
GO:0009987 Cellular process & 119 & $3.15 \mathrm{E}-03$ \\
GO:0044237 Cellular metabolic process & 113 & $4.87 \mathrm{E}-11$ \\
GO:0009117 Nucleotide metabolic process & 37 & $2.96 \mathrm{E}-12$ \\
GO:0016310 Phosphorylation & 22 & $2.60 \mathrm{E}-03$ \\
GO:0006629 Lipid metabolic process & 24 & $5.66 \mathrm{E}-04$ \\
\hline
\end{tabular}

Enrichment is analyzed using all differentially expressed proteins with foldchange of greater than $50 \%$ in MDA-AMP7, AVC1, RCB1280 and SNU487 cells cultivated in CAF-conditioned medium versus non-treated control cells $\left(\log _{2}\right.$ ratio of $>0.58, p$-value $<0.1$, two-tailed $t$-test, FDR $<0.05$ )

Abbreviations: CAF cancer associated fibroblast, $F D R$ false discovery rate

is to establish an experimental platform for the study of AMPAC biology.

Clinical data from patients treated at our center confirmed that intestinal subtype is a main prognostic factor and was significantly associated with KRT 20 and CDX2 expression and KRT7 negativity. A novel aspect was a significant association between intestinal differentiation and reduced features of EMT (tumor budding, ZEB1 and E-Cadherin expression). We were able to obtain and grow one cell line from each of the five reported patients (a total five AMPAC cell lines) under the same standard culture conditions. Basic characterization on the basis of markers for subtype and EMT revealed remarkable heterogeneity among these cell lines. However, hierarchical clustering analyses combining tumors and cell lines based on expression pattern suggested three main pattern: mesenchymal-like, PB, and INT differentiation. Interestingly, these observations also reflect the origin of the cell lines: two out of the three mesenchymal-like cell lines were isolated from metastases, where theoretically increased EMT features would be postulated. The AVC1 cells were derived from a moderately differentiated primary tumor, but displayed a loss of differentiation markers and partial EMT. The pancreatobiliary-like cell line SNU478 was derived from an AMPAC with signet ring cell features, which is a rare and aggressive tumor [53]. Loss of E-Cadherin by germline mutation is associated with diffuse gastric adenocarcinoma with signet ring cells [54]. Similarly, SNU478 has been shown to have the CDH1 gene repressed by DNA methylation [24] and displayed similarly high invasiveness as the mesenchymal-like cells.

Among the five cell lines, only one intestinal-like cell line (SNU869) was found, which is not surprising given that it was previously suggested that only the most aggressive tumor cells can be grown as cell lines in standard culture conditions [55]. Notably, SNU869 is the only cell line reported to be derived from a welldifferentiated primary AMPAC tumor. SNU869 cells displayed a markedly reduced growth and invasiveness compared to the other cell lines, as would be expected from clinical correlation. Interestingly, this intestinal-like cell line was not sensitive to low concentration of Gemcitabine, a drug often used to treat ampullary cancer. This is consistent with current clinical reports suggesting poor response or even reduced survival with Gemcitabinebased chemotherapy in intestinal type AMPAC [44, 56, 57].

Cancer associated fibroblasts (CAF) are known to promote tumorigenesis, invasion and metastasis $[58,59]$. Additionally, the prognostic value of CAF's immunohistochemical markers as well as stromal gene expression profiles have been previously reported [60-63]. However there is currently no standardized grading system to look at stromal CAF activity [63]. Here, we adopted a simple stromal grading system relying on morphological features of CAF [28] and noted increased CAF activation and EMT features in non-intestinal AMPAC. Therefore we tested the hypothesis in which CAF could enhance growth and induce EMT and a phenotypic shift in AMPAC cells through CAF secreted factors.

Treatment of AMPAC cells with CAF-CM from CAF isolated from a human AMPAC had several effects. In general, cellular growth and invasion were increased, ZEB1 expression increased and/or E-Cadherin expression decreased in the cell lines where these genes were expressed. With regard to AMPAC subtype marker expression, decrease of the intestinal markers KRT20 and CDX2 were observed. The cell line derived from signet ring cell AMPAC (SNU478) however displayed decreased cellular invasion, and increased CDX2 and KRT7 genes expression. The undifferentiated MDAAMP7 cell line showed a slight decrease compared to the very high ZEB1 baseline expression. These findings finding in which CAF-conditioned medium enhanced AMPAC cell growth and EMT features while suppressing intestinal markers and increasing KRT7 are well correlated with clinical data from histopathology and patient survival. It is also known that some cancer cell lines display a loss of differentiation markers and ECadherin in standard culture $[62,64,65]$. However these features were not observed in the five cell lines. 

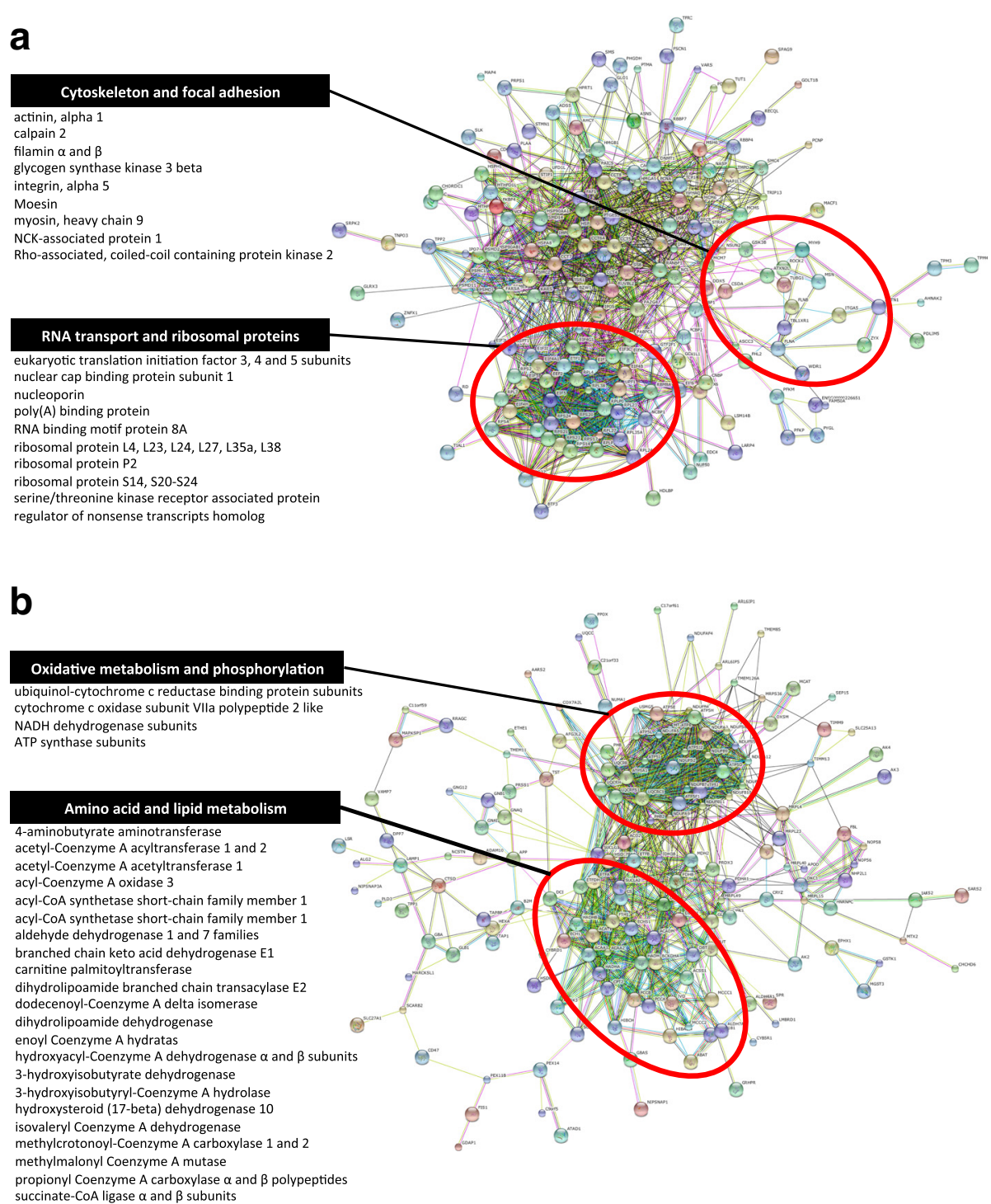

Fig. 9 Network visualization of differentially regulated proteins by STRING in AMPAC cells upon cultivation with CAF conditioned medium. Clustering of proteins were based on KEGG pathway for (a) up-regulated proteins in at least 3 cell lines ( $F C>0.58, p \leq 0.1)$, and (b) down-regulated proteins in at least 3 cell lines $(\mathrm{Fc}<-0.58, p \leq 0.1)$

Proteomic analysis revealed parallel regulation shifts in the mesenchymal- and pancreatobiliary-like cell lines. Pathophysiological pathways of cellular proliferation and survival, activation of the cytoskeleton and intracellular transport were up-regulated, whereas pathways of cell apoptosis, protein translation, oxidative, amino acid and lipid metabolism were down-regulated. These findings suggest a supportive role of CAF in AMPAC cell survival, proliferation and motility. Of note, the intestinal-like cell line SNU869 showed many of these regulation processes to respond in an opposite manner, suggesting CAF response to be differentiation-dependent in AMPAC. In addition, KRT20, CDX 2, KRT 7, ZEB 1 and CDH 1 were not consistently identified in all the cell lines (Additional file 1 :
Table S1, complete mass spectrometry data available via ProteomeXchange with identifier PXD002657). This is not surprising, as undersampling and partially incomplete overlap of proteome coverage is an intrinsic characteristic of mass-spectrometry based studies [45].

A major drawback of this study is that classification of cell lines relies on in vitro parameters and correlation with an independent clinical dataset from tumors. However, no information on the subtype of the tumors that the cell lines were derived from, nor patient follow-up, is available for validation of conclusions drawn. Up to now, this remains a general problem of virtually all standard cancer cell lines. Even the most advanced large scale cell line panel characterization studies have not 
Table 6 Gene Ontology (GO) functional enrichment analysis regulated proteins in ampullary cancer cells SNU869

\begin{tabular}{lll}
\hline GO terms of up-regulated proteins & Count & FDR \\
\hline $\begin{array}{l}\text { GO:0071840 Cellular component } \\
\text { organization or biogenesis }\end{array}$ & 148 & $4.19 \mathrm{E}-07$ \\
GO:0061024 Membrane organization & 47 & $7.99 \mathrm{E}-07$ \\
$\begin{array}{l}\text { GO:0016043 Cellular component } \\
\text { organization }\end{array}$ & 143 & $7.99 \mathrm{E}-07$ \\
GO:0044238 Primary metabolic process & 216 & $2.47 \mathrm{E}-06$ \\
GO:0044237 Cellular metabolic process & 213 & $2.83 \mathrm{E}-06$ \\
GO:0045184 Establishment of protein & 58 & $3.67 \mathrm{E}-06$ \\
localization & & \\
GO terms of down-regulated proteins & count & FDR \\
GO0043043: Peptide biosynthetic process & 30 & $1.18 \mathrm{E}-10$ \\
GO:0006412 Translation & 29 & $1.18 \mathrm{E}-10$ \\
GO:0043604 Amide biosynthetic process & 31 & $5.81 \mathrm{E}-10$ \\
GO:1901564 Organonitrogen compound & 61 & $1.24 \mathrm{E}-09$ \\
metabolic process & & \\
GO:0007005 Mitochondrion organization & 29 & $3.54 \mathrm{E}-09$ \\
GO:0006518 Peptide metabolic process & 30 & $5.57 \mathrm{E}-09$
\end{tabular}

Enrichment is analyzed using all differentially expressed proteins with foldchange of greater than $50 \%$ SNU869 cells cultivated in CAF-conditioned medium versus non-treated control cells $\left(\log _{2}\right.$ ratio of $>0.58, p$-value $<0.1$, two-tailed $t$-test, $\mathrm{FDR}<0.05$ )

Abbreviations: CAF cancer associated fibroblast, FDR false discovery rate

been validated using this approach [19-22]. Nevertheless, these studies suggest that cell lines do reflect important aspects of the clinical tumor biology, like marker expression and drug sensitivity.

\section{Conclusions}

On the basis of clustering for EMT features and subtype marker expression, most of the available AMPAC cell lines seem to reflect a poorly differentiated pancreatobiliary or mesenchymal-like phenotype, which is consistent with their state of origin from moderate to poorly differentiated primary tumors or metastases. Only SNU869, which is derived from a well-differentiated primary tumor, displays an intestinal phenotype and characteristically segregated from the other cell lines specifically in basic marker expression, drug sensitivity as well as proteomic CAF-response. Based on these findings, we therefore suggest that SNU869 is presently the most appropriate cell-based model for intestinal-like AMPAC, while others seem to reflect aggressive and metastatic AMPAC subtypes.

\section{Additional file}

Additional file 1: Table S1. List of up-regulated proteins identified from ampullary cancer cells cultivated with CAF conditioned medium. Table S2. List of down-regulated proteins identified from ampullary cancer cells treated with CAF conditioned medium. (DOCX 94 kb)

\section{Abbreviations}

AMPAC: ampullary adenocarcinoma; AT: atypical; ATCC: American TYPE CULTURE COLLECTION; CAF: cancer associated fibroblast; CDH1: E-cadherin; CDX2: caudal type homeobox 2; CM: conditioned medium; D: differentiated; DMEM: Dulbecco's modified Eagle's medium; DMSO: dimethyl sulfoxide; DNA: deoxyribonucleic acid; ECad: E-cadherin; EMT: epithelial-mesenchymal transition; G: histopathologic tumor grade; GO: gene ontology; H\&E: hematoxylin-eosin; HCL: hierarchical clustering; INT: intestinal; KEGG: Kyoto Encyclopedia of genes and genomes; KRT20: cytokeratin 20; KRT7: Cytokeratin 7; L: LYMPHANGIOSIS; LNR: Iymph node ratio; MES: mesenchymal-like; mRNA: messenger ribonucleic acid; MTT: 3-(4,5dimethylthiazol-2-yl)-2,5-diphenyltetrazolium bromide; PanCK: PanCytokeratin; PB: pancreatobiliary; PCR: polymerase chain reaction; PDAC: pancreatic ductal adenocarcinoma; POOR: poorly differentiated; R: resection margin status; STRING: Search Tool for the Retrieval of Interacting Genes/Proteins; T: histopathologic tumor stage; TNM: tumor-lymph nodesmetastasis classification; VIM: vimentin; ZEB1: zinc finger E-box binding homeobox 1.

\section{Competing interests}

The authors declare that they have no competing interests.

\section{Authors' contributions}

ZWL proteome comparison experiments and analyses, manuscript preparation and revision. LB in vitro experiments and drafting of the manuscript. HF immunohistochemistry and analysis. MLB mass spectrometry and analysis. UTH, FM, DB, TK performed the operations, patient follow-up, clinicopathologic case review, clinical statistics and critical revision of the manuscript. MW, PB histopathological workup and clinical statistics, critical revision of manuscript. AS, CS established ampullary cancer cell lines and critically revised the manuscript. OS, UFW, PB study design, coordination of experiments and manuscript draft. All authors read and approved the final manuscript.

\section{Acknowledgements}

ZWL is funded by Marie Curie IIF fellowship (Call Identifier: PIIF-GA-2012329622 GlycoMarker). OS is supported by grants of the Deutsche Forschungsgemeinschaft (DFG) (SCHI 871/2 and SCHI 871/5, SCHI 871/6, GR 1748/6, and INST 39/900-1) and the SFB850 (Project B8), a starting grant of the European Research Council (Programme "Ideas" - Call identifier: ERC-2011- StG 282111ProteaSys), and the Excellence Initiative of the German Federal and State Governments (EXC 294, BIOSS). UFW was supported by a research grant from the German Research Council (DFG-WE5085/1-1). The authors thank Franz Jehle for excellent technical assistance with mass spectrometry analysis.

\section{Author details}

${ }^{1}$ Institute of Molecular Medicine and Cell Research, University of Freiburg, Freiburg, Germany. ${ }^{2}$ Clinic for Surgery, UKSH Campus Lübeck, Lübeck, Germany. ${ }^{3}$ Department of Pathology, University Medical Center Freiburg, Freiburg, Germany. ${ }^{4}$ Clinic for General and Visceral Surgery, University Medical Center Freiburg, Freiburg, Germany. ${ }^{5}$ Dipartimento di Patologia, Universita di Verona, Verona, Italy. ${ }^{6}$ BIOSS Centre for Biological Signaling Studies, University of Freiburg, Freiburg, Germany. ${ }^{7}$ German Cancer Consortium (DKTK), German Cancer Research Center (DKFZ), D-69120 Heidelberg, Germany. ${ }^{8}$ Comprehensive Cancer Center Freiburg, Freiburg, Germany. ${ }^{9}$ Klinik für Chirurgie, Ratzeburger Allee 160, 23562 Lübeck, Germany.

Received: 27 August 2015 Accepted: 17 February 2016 Published online: 08 March 2016

\section{References}

1. Westgaard A, Pomianowska E, Clausen OPF, Gladhaug IP. Intestinal-type and pancreatobiliary-type adenocarcinomas: How does ampullary carcinoma differ from other periampullary malignancies? Ann Surg Oncol. 2013;20(2):430-9.

2. Pomianowska E, Grzyb K, Westgaard A, Clausen OPF, Gladhaug IP. Reclassification of tumour origin in resected periampullary adenocarcinomas reveals underestimation of distal bile duct cancer. Eur J Surg Onc. 2012; 38(11):1043-50

3. Bosman FT, Carneiro F, Hruban RH, Theise ND. WHO classification of tumours of the digestive system, fourth edition, vol. 3. 4th ed. Lyon: International Agency of Research in Cancer; 2010. 
4. Adsay V, Ohik N, Tajiri T, Kim GE, Krasinskas A, Balci S, Bagci P, Basturk O, Bandyopadhyay $S$, Jang $K T$, et al. Ampullary region carcinomas definition and site specific classification with delineation of four clinicopathologically and prognostically distinct subsets in an analysis of 249 cases. Am J Surg Pathol. 2012;36(11):1592-608.

5. Ohike N, Kim GE, Tajiri T, Krasinskas A, Basturk O, Coban I, Bandyopadhyay S, Morohoshi T, Goodman M, Kooby DA, et al. Intra-ampullary Papillary-Tubular Neoplasm (IAPN): characterization of tumoral intraepithelial neoplasia occurring within the ampulla a clinicopathologic analysis of 82 cases. Am J Surg Pathol. 2010;34(12):1731-48.

6. Bronsert P, Kohler I, Werner M, Makowiec F, Kuesters S, Hoeppner J, Hopt UT, Keck T, Bausch D, Wellner UF. Intestinal-type of differentiation predicts favourable overall survival: confirmatory clinicopathological analysis of 198 periampullary adenocarcinomas of pancreatic, biliary, ampullary and duodenal origin. BMC Cancer. 2013;13.

7. Westgaard A, Tafjord S, Farstad IN, Cvancarova M, Eide TJ, Mathisen O, Clausen OPF, Gladhaug IP. Pancreatobiliary versus intestinal histologic type of differentiation is an independent prognostic factor in resected periampullary adenocarcinoma. BMC Cancer. 2008;8.

8. Kawabata Y, Tanaka T, Nishisaka T, Inao T, Nishi T, Yano S. Cytokeratin 20 (CK20) and apomucin 1 (MUC1) expression in ampullary carcinoma: Correlation with tumor progression and prognosis. Diagn Pathol. 2010;5:75.

9. Chu PG, Schwarz RE, Lau SK, Yen Y, Weiss LM. Immunohistochemical staining in the diagnosis of pancreatobiliary and ampulla of Vater adenocarcinoma: application of CDX2, CK17, MUC1, and MUC2. Am J Surg Pathol. 2005;29(3):359-67.

10. Jun S-Y, Eom DW, Park H, Bae YK, Jang K-T, Yu E, Hong S-M. Prognostic significance of CDX2 and mucin expression in small intestinal adenocarcinoma. Mod Pathol. 2014;27(10):1364-74.

11. Morini S, Perrone G, Borzomati D, Vincenzi B, Rabitti C, Righi D, Castri F, Manazza AD, Santini D, Tonini G, et al. Carcinoma of the ampulla of vater morphological and immunophenotypical classification predicts overal survival. Pancreas. 2013;42(1):60-6.

12. Zhou H, Schaefer N, Wolff M, Fischer H-P. Carcinoma of the ampulla of Vater: comparative histologic/immunohistochemical classification and follow-up. Am J Surg Pathol. 2004;28(7):875-82.

13. Ehehalt $F$, Rümmele $P$, Kersting $S$, Lang-Schwarz $C$, Rückert $F$, Hartmann $A$, Dietmaier W, Terracciano L, Aust DE, Jahnke B, et al. Hepatocyte nuclear factor (HNF) 4a expression distinguishes ampullary cancer subtypes and prognosis after resection. Ann Surg. 2011;254(2):302-10.

14. Overman MJ, Zhang J, Kopetz S, Davies M, Zhi-Qin J, Stemke-Hale K, Rümmele P, Pilarsky C, Grützmann R, Hamilton, et al. Gene expression profiling of ampullary carcinomas classifies ampullary carcinomas into biliary-like and intestinal-like subtypes that are prognostic of outcome. PLoS One. 2013;8(6):e65144.

15. Ang DC, Shia J, Tang LH, Katabi N, Klimstra DS. The utility of immunohistochemistry in subtyping adenocarcinoma of the ampulla of vater. Am J Surg Pathol. 2014;38(10):1371-9.

16. Hanahan D, Weinberg RA. Hallmarks of cancer: the next generation. Cell. 2011;144(5):646-74.

17. Bronsert $\mathrm{P}$, Kohler I, Timme S, Kiefer S, Werner M, Schilling $O$, Vashist $Y$, Makowiec F, Brabletz T, Hopt UT, et al. Prognostic significance of Zinc finger E-box binding homeobox 1 (ZEB1) expression in cancer cells and cancer-associated fibroblasts in pancreatic head cancer. Surgery. 2014;156(1):97-108.

18. Ohike N, Coban I, Kim GE, Basturk O, Tajiri T, Krasinskas A, Bandyopadhyay S, Morohoshi T, Shimada Y, Kooby DA, et al. Tumor budding as a strong prognostic indicator in invasive ampullary adenocarcinomas. Am J Surg Pathol. 2010;34(10):1417-24.

19. Barretina J, Caponigro G, Stransky N, Venkatesan K, Margolin AA, Kim S, Wilson CJ, Lehar J, Kryukov GV, Sonkin D, et al. The cancer cell line encyclopedia enables predictive modeling of anticancer drug sensitivity. Nature. 2012;483(7391):603-7.

20. Garnett MJ, Edelman EJ, Heidorn SJ, Greenman CD, Dastur A, Lau KW, Greninger P, Thompson IR, Luo X, Soares J, et al. Systematic identification of genomic markers of drug sensitivity in cancer cells. Nature. 2012;483(7391):570-5.

21. Gillet J-P, Varma S, Gottesman MM. The clinical relevance of cancer cell lines. J Natl Cancer Inst. 2013;105(7):452-8.

22. Weinstein JN, Collisson EA, Mills GB, Shaw KM, Ozenberger BA, Ellrott K, Shmulevich I, Sander C, Stuart JM. The cancer genome atlas pan-cancer analysis project. Nat Genet. 2013;45(10):1113-20.
23. Frazier ML, Brown N, Pathak S, Mackay B, Cleary K, Olive M, Byrd DR, Evans DB, Levin B. Human cell-line from an adenocarcinoma of the ampulla of vater. In Vitro Cell Dev An. 1992;28A(3):149-53.

24. Ku JL, Yoon KA, Kim IJ, Kim WH, Jang JY, Suh KS, Kim SW, Park YH, Hwang $J H$, Yoon YB, et al. Establishment and characterisation of six human biliary tract cancer cell lines. Br J Cancer. 2002;87(2):187-93.

25. Peiper M, Alldinger I, Heller R, Pilarsky C, Schumacher U, Knoefel WT, Heinecke A, Izbicki JR. Biological and molecular characterization of a new human ampullary cancer cell line. Anticancer Res. 2003;23(1A):291-8.

26. Sorio C, Moore PS, Ennas MG, Tecchio C, Bonora A, Sartoris S, Balzarini P, Grigolato P, Scarpa A. A novel cell line and xenograft model of ampulla of Vater adenocarcinoma. Virchows Arch. 2004;444(3):269-77.

27. Kohler I, Bronsert P, Timme S, Werner M, Brabletz T, Hopt UT, Schilling O, Bausch D, Keck T, Wellner UF, et al. Detailed analysis of epithelial-mesenchymal transition and tumor budding identifies predictors of long-term survival in pancreatic ductal adenocarcinoma. J Gastroenterol Hepatol. 2015;30:78-84.

28. Ha SY, Yeo S-Y, Xuan Y-H, Kim S-H. The prognostic significance of cancerassociated fibroblasts in esophageal squamous cell carcinoma. PLoS One. 2014;9(6), e99955.

29. Saeed Al, Sharov V, White J, Li J, Liang W, Bhagabati N, Braisted J, Klapa M, Currier T, Thiagarajan M, et al. TM4: a free, open-source system for microarray data management and analysis. Biotechniques. 2003;34(2):374.

30. Eisen MB, Spellman PT, Brown PO, Botstein D. Cluster analysis and display of genome-wide expression patterns. Proc Natl Acad Sci U S A. 1998;95(25): 14863-8.

31. Ku JL, Yoon KA, Kim WH, Jang JY, Suh KS, Kim SW, Park YH, Park JG. Establishment and characterization of four human pancreatic carcinoma cell lines - Genetic alterations in the TGFBR2 gene but not in the MADH4 gene. Cell Tissue Res. 2002;308(2):205-14.

32. Bachem MG, Schneider E, Gross H, Weidenbach H, Schmid RM, Menke A, et al. Identification, culture, and characterization of pancreatic stellate cells in rats and humans. Gastroenterology. 1998;115(2):421-32.

33. Wellner U, Schubert J, Burk UC, Schmalhofer O, Zhu F, Sonntag A, Waldvogel B, Vannier C, Darling D, zur Hausen A, et al. The EMT-activator ZEB1 promotes tumorigenicity by repressing stemness-inhibiting microRNAs. Nat Cell Biol. 2009;11(12):1487-95.

34. Arumugam $T$, Ramachandran $V$, Fournier KF, Wang $H$, Marquis $L$, Abbruzzese JL, Gallick GE, Logsdon CD, McConkey DJ, Choi W, et al. Epithelial to mesenchymal transition contributes to drug resistance in pancreatic cancer. Cancer Res. 2009;69(14):5820-8.

35. Guo K, Ji CJ, Li L. Stable-isotope dimethylation labeling combined with LC-ESI MS for quantification of amine-containing metabolites in biological samples. Anal Chem. 2007;79(22):8631-8.

36. Boersema PJ, Raijmakers R, Lemeer S, Mohammed S, Heck AJR. Multiplex peptide stable isotope dimethyl labeling for quantitative proteomics. Nat Protoc. 2009;4(4):484-94.

37. Rappsilber J, Ishihama Y, Mann M. Stop and go extraction tips for matrixassisted laser desorption/ionization, nanoelectrospray, and LC/MS sample pretreatment in proteomics. Anal Chem. 2003;75(3):663-70.

38. Craig R, Beavis RC. TANDEM: matching proteins with tandem mass spectra. Bioinformatics. 2004;20(9):1466-7.

39. Keller A, Nesvizhskii Al, Kolker E, Aebersold R. Empirical statistical model to estimate the accuracy of peptide identifications made by MS/MS and database search. Anal Chem. 2002;74(20):5383-92.

40. Nesvizhskii Al, Keller A, Kolker E, Aebersold R. A statistical model for identifying proteins by tandem mass spectrometry. Anal Chem. 2003;75(17):4646-58.

41. Han DK, Eng J, Zhou HL, Aebersold R. Quantitative profiling of differentiation-induced microsomal proteins using isotope-coded affinity tags and mass spectrometry. Nat Biotechnol. 2001;19(10):946-51.

42. Vizcaino JA, Deutsch EW, Wang R, Csordas A, Reisinger F, Rios D, Dianes JA, Sun Z, Farrah T, Bandeira N, et al. ProteomeXchange provides globally coordinated proteomics data submission and dissemination. Nat Biotechnol. 2014;32(3):223-6.

43. Szklarczyk D, Franceschini A, Wyder S, Forslund K, Heller D, Huerta-Cepas J, Simonovic M, Roth A, Santos A, Tsafou KP, et al. STRING v10: protein-protein interaction networks, integrated over the tree of life. Nucleic Acids Res. 2015;43(D1):D447-52.

44. Jiang ZQ, Varadhachary G, Wang X, Kopetz S, Lee JE, Wang H, Shroff R, Katz $M$, Wolff RA, Fleming J, et al. A retrospective study of ampullary adenocarcinomas: overall survival and responsiveness to fluoropyrimidinebased chemotherapy. Ann Oncol. 2013;24(9):2349-53. 
45. Bronsert $\mathrm{P}$, Weisser J, Biniossek ML, Kuehs M, Mayer B, Drendel V, Timme S, Shahinian $\mathrm{H}$, Kusters $\mathrm{S}$, Wellner UF, et al. Impact of routinely employed procedures for tissue processing on the proteomic analysis of formalin-fixed paraffin-embedded tissue. Proteom Clin Appl. 2014;8(9-10):796-804.

46. Cameron JL, He J. Two thousand consecutive pancreaticoduodenectomies. J Am Coll Surgeons. 2015;220(4):530-6.

47. Fernandez-del Castillo C, Morales-Oyarvide V, McGrath D, Wargo JA, Ferrone CR, Thayer SP, et al. Evolution of the Whipple procedure at the Massachusetts General Hospital. Surgery. 2012;152(3 Suppl 1):S56-63.

48. He J, Ahuja N, Makary MA, Cameron JL, Eckhauser FE, Choti MA, et al. 2564 resected periampullary adenocarcinomas at a single institution: trends over three decades. HPB (Oxford). 2014;16(1):83-90.

49. Fischer H-P, Zhou H. Pathogenesis of carcinoma of the papilla of Vater. J Hepatobiliary Pancreat Surg. 2004;11(5):301-9.

50. Boone BA, Zeh HJ, Mock BK, Johnson PJ, Dvorchik I, Lee K, Moser AJ, Bartlett DL, Marsh JW. Resection of isolated local and metastatic recurrence in periampullary adenocarcinoma. HPB (Oxford). 2014;16(3):197-203.

51. de Jong MC, Tsai S, Cameron $J L$, Wolfgang CL, Hirose K, van Vledder MG, Eckhauser F, Herman JM, Edil BH, Choti MA, et al. Safety and efficacy of curative intent surgery for peri-ampullary liver metastasis. J Surg Oncol. 2010;102(3):256-63.

52. Winter JM, Cameron JL, Olino K, Herman JM, de Jong MC, Hruban RH, Wolfgang CL, Eckhauser F, Edil BH, Choti MA, et al. Clinicopathologic analysis of ampullary neoplasms in 450 patients: implications for surgical strategy and long-term prognosis. J Gastrointest Surg. 2010;14(2):379-87.

53. Wen XUE, Wu W, Wang BO, Yao H, Teng X. Signet ring cell carcinoma of the ampulla of Vater: Immunophenotype and differentiation. Oncol Lett. 2014;8(4):1687-92.

54. Hansford S, Kaurah P, Li-Chang $H$, Woo M, Senz J, Pinheiro $H$, Schrader KA, Schaeffer DF, Shumansky K, Zogopoulos G, et al. Hereditary diffuse gastric cancer syndrome: $\mathrm{CDH} 1$ mutations and beyond. JAMA Oncol. 2015;1(1):23-32.

55. Weinberg RA. The cells forming cancer cell lines develop without heterotypic interactions and deviate from behavior of cells within human tumors. In: Weinberg RA, editor. The biology of cancer. 2nd ed. New York: Taylor \& Francis Ltd; 2014. p. 585-7.

56. Neoptolemos JP, Moore MJ, Cox TF, Valle JW, Palmer DH, McDonald AC, Carter R, Tebbutt NC, Dervenis C, Smith D, et al. Effect of adjuvant chemotherapy with fluorouracil plus folinic acid or gemcitabine vs observation on survival in patients with resected periampullary adenocarcinoma: the ESPAC-3 periampullary cancer randomized trial. JAMA. 2012;308(2):147-56.

57. Schiergens TS, Reu S, Neumann J, Renz BW, Niess H, Boeck S, Heinemann V, Bruns CJ, Jauch K-W, Kleespies A. Histomorphologic and molecular phenotypes predict gemcitabine response and overall survival in adenocarcinoma of the ampulla of Vater. Surgery. 2015;158(1):151-61.

58. Kalluri R, Zeisberg M. Fibroblasts in cancer. Nat Rev Cancer. 2006;6(5):392-401.

59. Rybinski B, Franco-Barraza J, Cukierman E. The wound healing, chronic fibrosis and cancer progression triad. Physiol Genomics. 2014.

60. Finak G, Bertos N, Pepin F, Sadekova S, Souleimanova M, Zhao H, Chen HY, Omeroglu G, Meterissian S, Omeroglu A, et al. Stromal gene expression predicts clinical outcome in breast cancer. Nat Med. 2008;14(5):518-27.

61. Herrera M, Herrera A, Dominguez G, Silva J, Garcia V, Garcia JM, Gomez I, Soldevilla B, Munoz C, Provencio M, et al. Cancer-associated fibroblast and M2 macrophage markers together predict outcome in colorectal cancer patients. Cancer Sci. 2013;104(4):437-44.

62. Moffitt RA, Marayati R, Flate EL, Volmar KE, Loeza SGH, Hoadley KA, Rashid NU, Williams LA, Eaton SC, Chung AH, et al. Virtual microdissection identifies distinct tumor- and stroma-specific subtypes of pancreatic ductal adenocarcinoma. Nat Genet. 2015;47(10):1168.

63. Paulsson J, Micke $P$. Prognostic relevance of cancer-associated fibroblasts in human cancer. Semin Cancer Biol. 2014;25:61-8.

64. Collisson EA, Sadanandam A, Olson P, Gibb WJ, Truitt M, Gu SD, Cooc J, Weinkle J, Kim GE, Jakkula L, et al. Subtypes of pancreatic ductal adenocarcinoma and their differing responses to therapy. Nat Med. 2011;17(4):500-3.

65. Kang YA, Zhang R, Suzuki R, Li SQ, Rolfe D, Truty MJ, Chatterjees D, Thomas RM, Cardwell J, Wang Y, et al. Two-dimensional culture of human pancreatic adenocarcinoma cells results in an irreversible transition from epithelial to mesenchymal phenotype. Lab Invest. 2015;95(2):207-22.

\section{Submit your next manuscript to BioMed Central and we will help you at every step:}

- We accept pre-submission inquiries

- Our selector tool helps you to find the most relevant journal

- We provide round the clock customer support

- Convenient online submission

- Thorough peer review

- Inclusion in PubMed and all major indexing services

- Maximum visibility for your research

Submit your manuscript at www.biomedcentral.com/submit 